Published in final edited form as:

Inorg Chem. 2019 July 15; 58(14): 9213-9224. doi:10.1021/acs.inorgchem.9b00853.

\title{
Synthesis, Structure, Stability, and Inhibition of Tubulin Polymerization by Ru"-p-Cymene Complexes of Trimethoxyaniline-Based Schiff Bases
}

\author{
Sourav Acharya ${ }^{\dagger}$, Moumita Maji $^{\dagger}$, Ruturaj $^{\ddagger}$, Kallol Purkait ${ }^{\dagger}$, Arnab Gupta $^{\ddagger}$, Arindam \\ Mukherjee ${ }^{*}, \dagger, \S$ \\ tDepartment of Chemical Sciences, Indian Institute of Science Education and Research Kolkata, \\ Mohanpur, Nadia, West Bengal 741246, India \\ ‡Department of Biological Sciences, Indian Institute of Science Education and Research Kolkata, \\ Mohanpur, Nadia, West Bengal 741246, India \\ §Center for Advanced Functional Materials (CAFM), Indian Institute of Science Education and \\ Research Kolkata, Mohanpur, Nadia, West Bengal 741246, India
}

\begin{abstract}
Four trimethoxy- and dimethoxyphenylamine-based Schiff base (L1-L4)-bearing $\mathrm{Ru}^{\mathrm{II}}-p$-cymene complexes (1-4) of the chemical formula $\left[\mathrm{Ru}^{\mathrm{II}}\left(\eta^{6}-p\right.\right.$-cymene $\left.)(\mathrm{L})(\mathrm{Cl})\right]$ were synthesized, isolated in pure form, and structurally characterized using single-crystal X-ray diffraction and other analytical techniques. The complexes showed excellent in vitro antiproliferative activity against various forms of cancer that are difficult to cure, viz., triple negative human metastatic breast carcinoma MDA-MB-231, human pancreatic carcinoma MIA PaCa-2, and hepatocellular carcinoma Hep G2. The ${ }^{1} \mathrm{H}$ nuclear magnetic resonance data in the presence of $10 \%$ dimethylforma-mide- $d_{7}$ or dimethyl sulfoxide- $d_{6}$ in phosphate buffer (pD 7.4, containing $4 \mathrm{mM}$ $\mathrm{NaCl}$ ) showed that the complexes immediately generate the aquated species that is stable for at least $24 \mathrm{~h}$. Electrospray ionization mass spectrometry data showed that they do not bind with guanine nitrogen even in the presence of 5 molar equivalents of 9-EtG, during a period of $24 \mathrm{~h}$. The best complex in the series, $\mathbf{1}$, exhibits an $\mathrm{IC}_{50}$ of approximately $10-15 \mu \mathrm{M}$ in the panel of tested cancer cell lines. The complexes do not enhance the production of reactive oxygen species in the cells. Docking studies with a tubulin crystal structure (Protein Data Bank entry 1SAO) revealed that $\mathbf{1}$ and $\mathbf{3}$ as well as $\mathbf{L} \mathbf{1}$ and $\mathbf{L} 3$ have a high affinity for the interface of the $a$ and $\beta$ tubulin dimer in the colchicine binding site. The immunofluorescence studies showed that $\mathbf{1}$ and $\mathbf{3}$ strongly inhibited microtubule network formation in MDA-MB-231 cells after treatment with an $\mathrm{IC}_{20}$ or $\mathrm{IC}_{50}$ dose for $12 \mathrm{~h}$. The cell cycle analysis upon treatment with $\mathbf{1}$ showed that the complexes inhibit the mitotic phase because the arrest was observed in the G2/M phase. In
\end{abstract}

\footnotetext{
*Corresponding Author: a.mukherjee@iiserkol.ac.in.

Notes

The authors declare no competing financial interest.

Accession Codes

CCDC 1905422-1905424 contain the supplementary crystallographic data for this paper. These data can be obtained free of charge via www.ccdc.cam.ac.uk/data_request/cif, or by emailing data_request@ccdc.cam.ac.uk, or by contacting The Cambridge Crystallographic Data Centre, 12 Union Road, Cambridge CB2 1EZ, UK; fax: +44 1223336033.
} 
summary, $\mathbf{1}$ and $\mathbf{3}$ are Ru${ }^{\mathrm{II}}$ half-sandwich complexes that are capable of disrupting a microtubule network in a dose-dependent manner. They depolarize the mitochondria, arrest the cell cycle in the G2/M phase, and kill the cells by an apoptotic pathway.

\section{Introduction}

The serendipitous discovery of cisplatin by Rosenberg et al. led to intensive research of metal-based anticancer agents. ${ }^{1,2}$ Apart from Pt(II/IV), two other metals, Ru and Ga, have shown potential, and among them, a few complexes have found their place in clinical and/or preclinical trials. ${ }^{3-8} \mathrm{Ru}$ complexes have been found to be excellent candidates for overcoming cisplatin resistance with weaker side effects showing a different mechanism of action. ${ }^{9-12}$ Octahedral Ru ${ }^{\text {III }}$ complexes NAMI-A and NKP-1339 (Figure 1) have undergone clinical trials. ${ }^{13-15}$ However, NAMI-A was concluded to be not effective during a Phase II clinical trial, and NKP1339 has successfully completed a Phase I clinical trial against nonsmall-cell lung carcinoma (NSCLC) with minimum side effects. ${ }^{8,16,17}$ Though their mode of action is not totally understood, activation through reduction $\left(\mathrm{Ru}^{\mathrm{III}}-\mathrm{Ru}^{\mathrm{II}}\right)$ may be the pathway of activation, and they have both proteins and DNA as targets. On the other hand, organometallic half-sandwich $\mathrm{Ru}^{\mathrm{II}}$ complexes allow versatile modes of interaction and flexibility in the structure. Their mechanism of action varies depending on the attached ligand(s), arene moieties, ${ }^{18-21}$ and attached halides. ${ }^{22,23}\left[\mathrm{Ru}\left(\eta^{6}-\mathrm{C}_{12} \mathrm{H}_{10}\right)(\mathrm{en}) \mathrm{Cl}\right]-\left(\mathrm{PF}_{6}\right)(\mathbf{R M}$ 175), $\left[\mathrm{Ru}\left(\eta^{6}\right.\right.$ - $p$-cymene)(pta) $\left.\mathrm{Cl}_{2}\right]$ (RAPTA-C), and $\left[\mathrm{Ru}\left(\eta^{6}-\mathrm{C}_{6} \mathrm{H}_{5} \mathrm{Me}\right)(\mathrm{pta}) \mathrm{Cl}_{2}\right]$ (RAPTA-T), where en is ethane-1, 2-diamine and pta is 1,3,5-triaza -7-phosphatricyclo[3.3.1.1]decane, belong to the half-sandwich $\mathrm{Ru}^{\mathrm{II}}$ family of complexes that have undergone preclinical trials. $12,21,24-26 \mathbf{R M} 175$ with a labile $\mathrm{Ru}-\mathrm{Cl}$ bond is known as a DNA targeting molecule. On the other hand, the RAPTA class of complexes may target various proteins and show promising anti-metastatic effects in vivo and in vitro. ${ }^{27}$

The spectrum of activity of a metal-based drug is enhanced or tuned by incorporation of an organic directing molecule (ODM) as a ligand, giving researchers an opportunity to target various organelles or processes, viz., endoplasmic reticulum, ${ }^{28,29}$ lysosome, ${ }^{30,31}$ mitochondria, ${ }^{32,33}$ and tubulin polymerization. ${ }^{34-36}$ Tubulin polymerization involves the assembly of $a$ and $\beta$ tubulin hetero-dimers which leads to formation of the mitotic spindle apparatus that participates in cytoskeleton formation, intracellular transport, and cell division. Due to their crucial role in cell division (mitosis), microtubules are a clear target for anticancer chemotherapeutic drugs. ${ }^{37,38}$ There are two major types of microtubule-based anticancer agents. One group consists of the microtubule destabilizers that inhibit tubulin polymerization, viz., colchicine, combretastatin A-4, and vinca alkaloids (Figure 1), while the other type stabilizes microtubules by promoting tubulin polymerization, viz., taxanes. 39-41 These complexes inhibit the mitotic phase and inhibit the cell cycle at the G2/M phase, which ultimately leads to apoptosis. ${ }^{42}$

The recent advances showed that formation of Ru and Pt complexes with tubulin binding agents makes them efficient inhibitors of tubulin polymerization. Huang et al. showed that incorporation of different tubulin polymerization inhibitors into the axial position of $\mathrm{Pt}(\mathrm{IV})$ derivatives leads to toxicity that is higher than those of their corresponding $\mathrm{Pt}(\mathrm{II})$ analogues 
against cancer cell lines. ${ }^{34,35,43,44}$ These complexes showed equal potency toward cisplatin resistant and sensitive cell lines. Recently, Sadler et al. synthesized $\mathrm{Ru}^{\mathrm{II}}$ arene derivatives of $N$-tosyl-1,2-diphenylethane-1,2-diamine, which were found to accumulate in the cytosol and inhibit tubulin polymerization. ${ }^{45}$ Inspired by colchicine and combretastatin, many new tubulin polymerization inhibitors have been designed. ${ }^{46,47}$ Some of them show promising inhibition of microtubule formation and good antiproliferative activities. The structureactivity relationship suggests the importance of the trimethoxyphenyl (TMP) moiety in their chemical structure. This TMP moiety is present in combretastatine A4 and colchicine and seems to be very crucial for inhibiting tubulin polymerization. ${ }^{48-51}$ Keeping that in mind, we have designed $\mathrm{Ru}^{\mathrm{II}}-p$-cymene complexes of four different Schiff bases containing trimethoxy- and dimethoxyaniline as a part of the ligand system. Docking studies with the ligands suggested that they may present an orientation that can inhibit tubulin polymerization by binding to the same active site as colchicine, during microtubule formation by $a$ and $\beta$ tubulins. Hence, we have synthesized four complexes 1-4 with the chemical formula $\left[\mathrm{Ru}^{\mathrm{II}}\left(\eta^{6}-p\right.\right.$-cymene $\left.)(\mathrm{L})(\mathrm{Cl})\right]$ and structurally characterized them using single-crystal X-ray diffraction and other analytical techniques. These complexes have been analyzed with respect to their stability in aqueous solutions and evaluated for their ability to inhibit tubulin polymerization along with in vitro cytotoxicity in various cancer cell lines.

\section{Experimental Section}

\section{Materials and Methods}

The chemicals were purchased from multiple commercial sources and used without further purification. The solvents were distilled and dried using standard procedures, prior to use. The metal precursor complex $\left[\mathrm{Ru}\left(\eta^{6}-p \text {-cym }\right) \mathrm{Cl}_{2}\right]_{2}$ was synthesized following a known literature procedure. ${ }^{52}$ MTT [3-(4,5-dimethylthiazol-2-yl)-2,5-diphenyltetrazolium bromide] (USB) and all kinds of supplements and assay kits were purchased from Gibco and used as received. Anti-tubulin antibodies were purchased from Abcam. All of the solvents used for spectroscopic measurements were of spectroscopy grade and purchased from Spectrochem, India. Ultraviolet-visible (UV-vis) spectroscopic measurements were taken using an Agilent Technologies Cary 300 Bio spectrophotometer. The FT-IR spectra were recorded using a PerkinElmer SPECTRUM RX I spectrometer in $\mathrm{KBr}$ pellets. The ${ }^{1} \mathrm{H}$ and ${ }^{13} \mathrm{C}$ nuclear magnetic resonance (NMR) spectra were recorded using a $400 \mathrm{MHz}$ JEOL ECS or $500 \mathrm{MHz}$ Bruker Avance III spectrometer, at room temperature $\left(24-27^{\circ} \mathrm{C}\right)$. The chemical shifts $(\delta)$ of the relevant compounds are reported in parts per million. All of the mass spectra (ESIHRMS) were recorded in positive electrospray ionization mode using a Bruker maXis II instrument. Elemental analyses were performed with a PerkinElmer 2400 series II CHNS/O analyzer. Isolated yields of ${ }^{1} \mathrm{H}$ NMR pure compounds are reported.

\section{Syntheses}

\section{Synthesis of 2-\{[(3,4,5-Trimethoxyphenyl)imino]-methyl\}phenol (L1)—L1 was}

synthesized according to the literature procedure ${ }^{53}$ with some modifications. 3,4,5-

Trimethoxyaniline $(5 \mathrm{mmol})$ and salicylaldehyde $(5 \mathrm{mmol})$ were dissolved in methanol and refluxed for $12 \mathrm{~h}$ in the presence of a catalytic amount of formic acid. After completion of the reaction, the reaction mixture was concentrated and kept in an ice bath for $1 \mathrm{~h}$, from 
which L1 precipitated as a yellow solid. This solid was washed with petroleum ether and finally dried in a vacuum desiccator. Yield: $82 \%$. $\left.1 \mathrm{H} \mathrm{NMR} \mathrm{(400} \mathrm{MHz}, \mathrm{CDCl}_{3}, 298 \mathrm{~K}\right) \delta$ : $13.12(1 \mathrm{H}, \mathrm{s}, \mathrm{OH}), 8.54(1 \mathrm{H}, \mathrm{s}, \mathrm{CH}=\mathrm{N}), 7.34-7.19(2 \mathrm{H}, \mathrm{m}, \mathrm{Ar}-\mathrm{H}), 6.95(1 \mathrm{H}, \mathrm{d}, J=8.3 \mathrm{~Hz}$, $\mathrm{Ar}-\mathrm{H}), 6.88(1 \mathrm{H}, \mathrm{t}, J=7.6 \mathrm{~Hz}, \mathrm{Ar}-\mathrm{H}), 6.46(2 \mathrm{H}, \mathrm{s}, \mathrm{Ar}-\mathrm{H}), 3.84(6 \mathrm{H}, \mathrm{s}, \mathrm{OMe}), 3.80(3 \mathrm{H}, \mathrm{s}$, OMe) (Figure S1). ${ }^{13} \mathrm{C} \mathrm{NMR}\left(125 \mathrm{MHz}, \mathrm{CDCl}_{3}, 298 \mathrm{~K}\right) \delta: 161.7,161.1,153.8,137.39$, 133.7, 133.4, 132.2, 119.2, 118.8, 117.3, 98.5, 61.0, 56.2 (Figure S2).

\section{Synthesis of 2-\{[(3,4-Dimethoxyphenyl)imino]methyl\}phenol (L2)—L2 was}

synthesized according to the literature procedure ${ }^{54}$ with some modifications. 3,4Dimethoxyaniline $(5 \mathrm{mmol})$ and salicylaldehyde $(5 \mathrm{mmol})$ were dissolved in methanol and refluxed for $12 \mathrm{~h}$. After completion of the reaction, the reaction mixture was evaporated to dryness. Then the solid mass was washed with petroleum ether, redissolved in diethyl ether, and filtered. The filtrate was evaporated to dryness and then dried in a vacuum desiccator. The solid was washed with petroleum ether and finally dried in a vacuum desiccator. Yield: 87\%. ${ }^{1} \mathrm{H}$ NMR (400 MHz, DMSO- $\left.d_{6}, 298 \mathrm{~K}\right) \delta: 13.32(1 \mathrm{H}, \mathrm{s}, \mathrm{OH}), 8.96(1 \mathrm{H}, \mathrm{s}, \mathrm{CH}=\mathrm{N})$, $7.62(1 \mathrm{H}, \mathrm{d}, J=8.0 \mathrm{~Hz}, \mathrm{Ar}-\mathrm{H}), 7.38(1 \mathrm{H}, \mathrm{m}, \mathrm{Ar}-\mathrm{H}), 7.14(1 \mathrm{H}, \mathrm{d}, J=2.2 \mathrm{~Hz}, \mathrm{Ar}-\mathrm{H}), 7.01$ $(4 \mathrm{H}, \mathrm{m}, \mathrm{Ar}-\mathrm{H}), 3.83$ (3H, s, OMe), $3.78\left(3 \mathrm{H}, \mathrm{s}, \mathrm{OMe}\right.$ ) (Figure S3). ${ }^{13} \mathrm{C} \mathrm{NMR}(125 \mathrm{MHz}$, DMSO- $\left.d_{6}, 298 \mathrm{~K}\right) \delta: 161.2,160.1,149.3,148.2,140.8,132.7,132.2,119.3,118.9,116.4$, 113.9, 112.0, 105.0, 55.6, 55.6 (Figure S4).

\section{Synthesis of 2-Methoxy-6-\{[(3,4,5-trimethoxyphenyl)imino]-methyl\}phenol (L3)}

$-3,4,5$-Trimethoxyaniline $(5 \mathrm{mmol})$ and $o$-vaniline $(5 \mathrm{mmol})$ were dissolved in methanol and refluxed for $12 \mathrm{~h}$. The solution was then brought to room temperature and evaporated to dryness. The orange mass was then washed several times with petroleum benzene, sonicated, and washed with cold diethyl ether. This solid was further purified by recrystallization from ethanol. Yield: 95\%. ${ }^{1} \mathrm{H}$ NMR (400 MHz, DMSO- $\left.d_{6}, 298 \mathrm{~K}\right) \delta: 13.29(1 \mathrm{H}, \mathrm{s}, \mathrm{OH}), 8.96$ $(1 \mathrm{H}, \mathrm{s}, \mathrm{CH}=\mathrm{N}), 7.22(1 \mathrm{H}, \mathrm{d}, J=7.6 \mathrm{~Hz}, \mathrm{Ar}-\mathrm{H}), 7.12(1 \mathrm{H}, \mathrm{d}, J=7.6 \mathrm{~Hz}, \mathrm{Ar}-\mathrm{H}), 6.91(1 \mathrm{H}, \mathrm{t}$, $J=7.6 \mathrm{~Hz}, \mathrm{Ar}-\mathrm{H}), 6.78(2 \mathrm{H}, \mathrm{s}, \mathrm{Ar}-\mathrm{H}), 3.84-3.82(6 \mathrm{H}, \mathrm{s}, \mathrm{OMe}), 3.68$ (3H, s, OMe) (Figure S5) ${ }^{13} \mathrm{C}$ NMR (125 MHz, DMSO- $\left.d_{6}, 298 \mathrm{~K}\right) \delta: 162.8,153.3,150.5,147.8,143.5,136.6$, 123.8, 119.1, 118.5, 115.5, 99.0, 60.1, 55.9, 55.8. (Figure S6).

\section{Synthesis of 2-\{[(3,4-Dimethoxyphenyl)imino]methyl\}phenol (L4)-This} compound was synthesized by the same procedure discussed above for L2. Yield: $73 \%$. ${ }^{1} \mathrm{H}$ NMR (400 MHz, CDCl $3,298 \mathrm{~K}) \delta: 13.72(1 \mathrm{H}, \mathrm{s}, \mathrm{OH}), 8.55\left({ }^{1} \mathrm{H}, \mathrm{s}, \mathrm{CH}=\mathrm{N}\right), 6.96-6.90(2 \mathrm{H}$, $\mathrm{m}, \mathrm{Ar}-\mathrm{H}), 6.83-6.81$ (4H, m, Ar-H), 3.86 (6H, s, OMe), 3.84 (3H, s, OMe) (Figure S7). ${ }^{13} \mathrm{C}$ NMR $\left(125 \mathrm{MHz}, \mathrm{CDCl}_{3}, 298 \mathrm{~K}\right) \delta: 160.5,151.3,149.6,148.4,141.4,123.5,119.1$, $118.4,114.5,112.9,111.5,105.1,56.2,56.1,55.9$ (Figure S8).

\section{Syntheses of Metal Complexes (1-4)}

General Procedure for the Synthesis of Metal Complexes (1-4)-The respective ligand $(0.1 \mathrm{mmol})$ was dissolved in degassed methanol $(10 \mathrm{~mL})$ followed by addition of $\mathrm{KOH}(0.1 \mathrm{mmol})$, and then the solution was allowed to stir for $15 \mathrm{~min}$. Then, a methanolic solution of $\left[\mathrm{Ru}(p \text {-cym }) \mathrm{Cl}_{2}\right]_{2}(0.1 \mathrm{mmol})$ was added in the dark under a nitrogen atmosphere at room temperature. The resultant solution was stirred at room temperature for $12 \mathrm{~h}$. The entire solution was then evaporated to dryness, which gave a yellowish-orange product that 
was washed several times with diethyl ether and ultimately purified by column chromatography in alumina with a 1:1 dichloromethane/acetone mixture.

Rull(p-cym)(L1)Cl (1)—Yield: 56\%. ${ }^{1} \mathrm{H}$ NMR (400 MHz, DMSO- $\left.d_{6}, 298 \mathrm{~K}\right) \delta: 9.56(1 \mathrm{H}$, d, $J=5.4 \mathrm{~Hz}, \mathrm{Ar}-\mathrm{H}), 8.86(1 \mathrm{H}, \mathrm{s}, \mathrm{CH}=\mathrm{N}), 8.31-8.25(2 \mathrm{H}, \mathrm{m}, \mathrm{Ar}-\mathrm{H}), 7.88(1 \mathrm{H}, \mathrm{t}, J=6.0$ $\mathrm{Hz}, \mathrm{Ar}-\mathrm{H}), 7.16(2 \mathrm{H}, \mathrm{s}, \mathrm{Ar}-\mathrm{H}), 6.06(1 \mathrm{H}, \mathrm{d}, J=4.3 \mathrm{~Hz}, p$-cym-H), $5.77(2 \mathrm{H}, \mathrm{m}, p$-cym-H), $5.60(1 \mathrm{H}, \mathrm{d}, J=6.1 \mathrm{~Hz}, p$-cym-H), $3.88(6 \mathrm{H}, \mathrm{s}, \mathrm{OMe}), 3.77(3 \mathrm{H}, \mathrm{s}, \mathrm{OMe}), 2.53(1 \mathrm{H}, \mathrm{m}, p-$ cym-isopropyl-CH), 2.17 (3H, s, p-cym-Me), 1.01 (6H, d, $J=6.8 \mathrm{~Hz}, p$-cym-isopropyl) (Figure S9). ${ }^{13} \mathrm{C}$ NMR $\left(125 \mathrm{MHz}\right.$, DMSO- $\left.d_{6}, 298 \mathrm{~K}\right) \delta: 164.8,164.0,154.0,152.2,135.8$, 135.5, 134.7, 121.5, 118.3, 112.9, 101.3, 100.2, 96.9, 85.5, 83.4, 82.4, 80.7, 60.1,55.9, 29.8, 22.1, 21.3, 17.8 (Figure S10). UV-vis [MeOH, $\left.\lambda_{\max }, \mathrm{nm}\left(\varepsilon, \mathrm{M}^{-1} \mathrm{~cm}^{-1}\right)\right]: 294$ (8490), 405 (3350). IR (KBr pellets, $\mathrm{cm}^{-1}$ ): 1608, 1440, 1231 (Figure S17A). ESI-HRMS (MeOH) $\mathrm{m} / z$. (exp) 522.1221 (522.1213) $\left[\mathrm{Ru}^{\mathrm{II}} \mathrm{C}_{26} \mathrm{H}_{30} \mathrm{NO}_{4}{ }^{+}\right]$. Anal. Calcd for $\mathrm{C}_{26} \mathrm{H}_{30} \mathrm{ClNO}_{4} \mathrm{Ru}$ : C, 56.06; H, 5.43; N, 2.51. Found: C, 56.24; H, 5.41; N, 2.53. Mp: $178{ }^{\circ} \mathrm{C}$.

Rull(p-cym)(L2)Cl (2)—Yield: 60\%. ${ }^{1} \mathrm{H}$ NMR (500 MHz, DMSO- $\left.d_{6}, 298 \mathrm{~K}\right) \delta: 7.90(1 \mathrm{H}$, s, CH=N), $7.42(1 \mathrm{H}, \mathrm{d}, J=1.5 \mathrm{~Hz}, \mathrm{Ar}-\mathrm{H}), 7.15-7.10(3 \mathrm{H}, \mathrm{m}, \mathrm{Ar}-\mathrm{H}), 7.03(1 \mathrm{H}, \mathrm{d}, J=8.5$ $\mathrm{Hz}, \mathrm{Ar}-\mathrm{H}), 6.72(1 \mathrm{H}, \mathrm{d}, J=3.5 \mathrm{~Hz}, \mathrm{Ar}-\mathrm{H}), 6.35(1 \mathrm{H}, \mathrm{t}, J=7 \mathrm{~Hz}, \mathrm{Ar}-\mathrm{H}), 5.4(1 \mathrm{H}, \mathrm{d}, J=6.0$ $\mathrm{Hz}, p$-cym-H), $5.34(1 \mathrm{H}, \mathrm{d}, J=6.0 \mathrm{~Hz}, p$-cym-H), $5.14(1 \mathrm{H}, \mathrm{d}, J=6.0 \mathrm{~Hz}, p$-cym-H), 4.36 $(1 \mathrm{H}, \mathrm{d}, J=5.5 \mathrm{~Hz}, p$-cym-H), $3.82(3 \mathrm{H}, \mathrm{s}, \mathrm{OMe}), 3.81(3 \mathrm{H}, \mathrm{s}, \mathrm{OMe}), 2.00$ (3H, s, $p$-cym$\mathrm{Me}), 1.10$ (3H, d, $J=6.5 \mathrm{~Hz}, p$-cym-isopropyl), 1.07 (3H, d, $J=7.0 \mathrm{~Hz}, p$-cym-isopropyl) (Figure S11). ${ }^{13} \mathrm{C}$ NMR $\left(125 \mathrm{MHz}\right.$, DMSO- $\left.d_{6}, 298 \mathrm{~K}\right) \delta: 164.8,163.8,152.1,148.1,147.3$, 135.6, 134.6, 121.5, 118.5, 114.4, 112.9, 111.0, 108.5, 99.9, 97.4, 86.1, 83.0, 82.5, 81.1, 55.7, 55.5, 29.9, 22.2, 21.4, 18.0 (Figure S12). UV-vis [MeOH, $\left.\lambda_{\max }, \mathrm{nm}\left(\varepsilon, \mathrm{M}^{-1} \mathrm{~cm}^{-1}\right)\right]$ : 295 (8650), 405 (3350). IR (KBr pellets, $\mathrm{cm}^{-1}$ ): 1610, 1445, 1233 (Figure S17B). ESIHRMS (MeOH) $m / z$. (exp) 492.1161 (492.1107) $\left[\mathrm{Ru}^{\mathrm{II}} \mathrm{C}_{25} \mathrm{H}_{28} \mathrm{NO}_{3}{ }^{+}\right.$. Anal. Calcd for $\mathrm{C}_{25} \mathrm{H}_{28} \mathrm{ClNO}_{3} \mathrm{Ru}$ : C, 56.98; H, 5.36; N, 2.66. Found: C, 57.14; H, 5.39; N, 2.68. Mp: 176 ${ }^{\circ} \mathrm{C}$.

Rull(p-cym)(L3)Cl (3)—Yield: 56\%. ${ }^{1} \mathrm{H}$ NMR (400 MHz, CDCl 3 , $\left.298 \mathrm{~K}\right) \delta: 7.77$ (1H, s, $\mathrm{CH}=\mathrm{N}), 6.97(2 \mathrm{H}, \mathrm{d}, J=8.0 \mathrm{~Hz}, \mathrm{Ar}-\mathrm{H}), 6.74\left(1 \mathrm{H}, \mathrm{dd}, J_{1}=7.5 \mathrm{~Hz}, J_{2}=1.5 \mathrm{~Hz}, \mathrm{Ar}-\mathrm{H}\right), 6.59$ $\left(1 \mathrm{H}, \mathrm{dd}, J_{1}=7.5 \mathrm{~Hz}, J_{2}=1.5 \mathrm{~Hz}, \mathrm{Ar}-\mathrm{H}\right), 6.36(1 \mathrm{H}, \mathrm{t}, J=8.4 \mathrm{~Hz}, \mathrm{Ar}-\mathrm{H}), 5.36(1 \mathrm{H}, \mathrm{d}, J=6.1$ $\mathrm{Hz}, p$-cym-H), $5.31(1 \mathrm{H}, \mathrm{d}, J=6.0 \mathrm{~Hz}, p$-cym-H), $5.1(1 \mathrm{H}, \mathrm{d}, J=6.0 \mathrm{~Hz}, p$-cym-H $), 4.4(1 \mathrm{H}$, d, $J=5.3 \mathrm{~Hz}, p$-cym-H), $3.92(6 \mathrm{H}, \mathrm{s}, \mathrm{OMe}), 3.89$ (3H, s, OMe), $3.82(3 \mathrm{H}, \mathrm{s}, \mathrm{OMe}), 2.82$ $(1 \mathrm{H}, \mathrm{m}, p$-cymisopropyl-CH), $2.6(3 \mathrm{H}, \mathrm{s}, p$-cym-Me) $1.17(3 \mathrm{H}, \mathrm{d}, J=6.8 \mathrm{~Hz}, p$ cymisopropyl), 1.12 (3H, d, $J=6.8 \mathrm{~Hz}, p$-cym-isopropyl) (Figure S13). ${ }^{13} \mathrm{C}$ NMR (125 $\left.\mathrm{MHz}, \mathrm{CDCl}_{3}, 298 \mathrm{~K}\right) \delta: 163.6,154.4,153.1,152.3,136.5,126.4,117.7,114.8,113.8,101.7$, 101.5, 98.6, 83.8, 81.0, 80.5, 80.5, 61.1, 56.5, 56.7, 30.5, 22.1, 21.3, 18.9 (Figure S14). IR $\left(\mathrm{KBr}\right.$ pellets, $\left.\mathrm{cm}^{-1}\right): 1608,1440,1231$. ESI-HRMS $(\mathrm{MeOH}) \mathrm{m} / z .(\exp ) 552.1319$ (552.1218) [ $\mathrm{Ru}^{\mathrm{II}} \mathrm{C}_{27} \mathrm{H}_{32} \mathrm{NO}_{5}{ }^{+}$]. UV-vis [MeOH, $\lambda_{\max }, \mathrm{nm}\left(\varepsilon, \mathrm{M}^{-1} \mathrm{~cm}^{-1}\right)$ ]: 272 (10500), 306 (9670), 420 (3180) (Figure S17C). Anal. Calcd for $\mathrm{C}_{27} \mathrm{H}_{32} \mathrm{ClNO}_{5} \mathrm{Ru}$ : C, 55.24; H, 5.49; $\mathrm{N}, 2.39$. Found: $\mathrm{C}, 55.04 ; \mathrm{H}, 5.50 ; \mathrm{N}, 2.38$. Mp: $180^{\circ} \mathrm{C}$.

Ru'l(p-cym)(L4)Cl (4)—Yield: 56\%. ${ }^{1} \mathrm{H}$ NMR (125 MHz, DMSO-d $\left.d_{6}, 298 \mathrm{~K}\right) \delta: 7.87\left({ }^{1} \mathrm{H}\right.$, s, CH=N), $7.4\left({ }^{1} \mathrm{H}, \mathrm{d}, J=2.0 \mathrm{~Hz}, \mathrm{Ar}-\mathrm{H}\right), 7.12\left({ }^{1} \mathrm{H}, \mathrm{m}, \mathrm{Ar}-\mathrm{H}\right), 7.0\left({ }^{1} \mathrm{H}, \mathrm{d}, J=8.5 \mathrm{~Hz}, \mathrm{Ar}-\mathrm{H}\right)$, 
$6.76(2 \mathrm{H}, \mathrm{d}, J=8.0 \mathrm{~Hz}, \mathrm{Ar}-\mathrm{H}), 6.2\left({ }^{1} \mathrm{H}, \mathrm{t}, J=7.5 \mathrm{~Hz}, \mathrm{Ar}-\mathrm{H}\right), 5.4\left({ }^{1} \mathrm{H}, \mathrm{d}, J=6.0 \mathrm{~Hz}, p\right.$-cym$\mathrm{H}), 5.3\left({ }^{1} \mathrm{H}, \mathrm{d}, J=6.0 \mathrm{~Hz}, p\right.$-cym-H), $5.16\left({ }^{1} \mathrm{H}, \mathrm{d}, J=6.0 \mathrm{~Hz}, p\right.$-cym-H $), 4.4\left({ }^{1} \mathrm{H}, \mathrm{d}, J=6.0\right.$ $\mathrm{Hz}, p$-cym-H), 3.82 (3H, s, OMe), 3.81 (3H, s, OMe), 3.7 (3H, s, OMe), 2.8 (3H, s, p-cym$\mathrm{Me}), 1.1(3 \mathrm{H}, \mathrm{d}, J=7.0 \mathrm{~Hz}, p$-cym-isopropyl), $1.05(3 \mathrm{H}, \mathrm{d}, J=7.0 \mathrm{~Hz}, p$-cym-isopropyl) (Figure S15). ${ }^{13} \mathrm{C}$ NMR $\left(125 \mathrm{MHz}\right.$, DMSO- $\left.d_{6}, 298 \mathrm{~K}\right) \delta: 163.5,156.3,152.1,151.9,148.0$, 147.3, 127.1, 118.1, 115.1, 114.4, 111.9, 111.0, 108.5, 99.9, 97.4, 85.9, 82.8, 82.5, 81.1, 55.7, 55.5, 29.8, 22.1, 21.3, 17.9 (Figure S16). UV-vis [MeOH, $\lambda_{\max }, \mathrm{nm}\left(\varepsilon, \mathrm{M}^{-1} \mathrm{~cm}^{-1}\right)$ ]: 275 (10400), 307 (9550), 409 (3050) (Figure S17D). IR (KBr pellets, $\mathrm{cm}^{-1}$ ): 1605, 1464, 1183. ESI-HRMS (MeOH) $\mathrm{m} / z$. (exp) 522.1247 (522.1213) $\left[\mathrm{Ru}^{\mathrm{II}} \mathrm{C}_{26} \mathrm{H}_{30} \mathrm{NO}_{4}{ }^{+}\right]$. Anal. Calcd for $\mathrm{C}_{26} \mathrm{H}_{30} \mathrm{ClNO}_{4} \mathrm{Ru}$ : C, 56.06; H, 5.43; N, 2.51. Found: C, 56.32; H, 5.44; N, 2.49. Mp: $179^{\circ} \mathrm{C}$.

\section{X-ray Crystallography}

Single crystals of a complex $(\mathbf{1}, \mathbf{3}$, or $\mathbf{4})$ were obtained by slow evaporation from a methanolic solution at room temperature. A suitable single crystal was selected and mounted over a loop of the goniometer of a SuperNova, dual, $\mathrm{Cu}$ at zero, Eos diffractometer. The crystal was kept at 100.00(1) K during data collection to minimize the probability volume of the ellipsoids. The X-ray source used to collect data was Mo Ka. Data reduction was performed in CrysAlisPro171.37.33c, and finally, the structure was determined with the Superflip ${ }^{55}$ structure solution program using Charge Flipping and refined with the ShelXL ${ }^{56}$ refinement package using Least Squares minimization in Olex2. ${ }^{57}$ The CCDC numbers are 1905422 (1), 1905423 (3), and 1905424 (4).

\section{Solution Stability Study}

Stabilities of the complexes (1-3) and the ligands ( $\mathbf{L} 1$ and $\mathbf{L 3}$ ) were determined by ${ }^{1} \mathrm{H}$ NMR using DMSO- $d_{6} / \mathrm{DMF}-d_{7}$ and a $20 \mathrm{mM}$ phosphate buffer mixture (pD 7.4) containing $4 \mathrm{mM}$ $\mathrm{NaCl}[1: 9(\mathrm{v} / \mathrm{v})]$ at $25{ }^{\circ} \mathrm{C}$ at different time points up to $24 \mathrm{~h}$. The buffer solution was degassed prior to use.

\section{Distribution Coefficient Determination}

Distribution coefficients of the three complexes in an octanol-water system were determined using the standard shake-flask method. Each set was performed in triplicate, and the absorbance was recorded in a UV-vis spectrophotometer using proper dilution. The concentration of the substances in each layer was calculated using the respective molar extinction coefficients of $\mathbf{1 - 4}$, and the distribution coefficient values $\left(\log D_{\mathrm{o} / \mathrm{w}}\right)$ were obtained from the ratio.

\section{Cell Lines and Culture Conditions}

Human pancreatic carcinoma (MIA PaCa-2), triple negative human metastatic breast adenocarcinoma (MDA-MB-231), and human hepatocellular carcinoma (Hep G2) cells were obtained from NCCS (Pune, India). The cells were grown in T-75 flasks as adherent monolayers in a 5\% carbon dioxide atmosphere using a culture medium, supplemented with $10 \%$ fetal bovine serum (GIBCO) and antibiotics (100 units $\mathrm{mL}^{-1}$ penicillin and $100 \mu \mathrm{g} \mathrm{mL}$ ${ }^{-1}$ streptomycin). Hep G2 cells were grown in minimal essential medium (MEM), while 
MIA PaCa-2 and MDA-MB-231 cells were cultured in Dulbecco's modified Eagle's medium (DMEM) and in a 1:1 mixture of DMEM with Ham's F12 nutrient mixture (i.e., DMEM/F-12), respectively. All cell lines were maintained in their logarithmic phase of growth before each experiment and plated when they reached $70 \%$ confluency.

\section{Cell Viability Assay}

The growth inhibitory effect toward tumor cell lines (MDA-MB-231, Hep G2, and MIA $\mathrm{PaCa}-2$ ) was evaluated with the help of the MTT assay. In brief, $6 \times 10^{3}$ cells per well were seeded in 96-well microplates in respective media $(200 \mu \mathrm{L})$ and incubated at $37{ }^{\circ} \mathrm{C}$ in a $5 \%$ carbon dioxide atmosphere. In case of hypoxia, the oxygen level was maintained at $1.5 \%$ and cells were grown under this condition for at least two passages; thereafter, they were used for the MTT assay as described below. After incubation for $48 \mathrm{~h}$, the medium was renewed with fresh medium ( $200 \mu \mathrm{L}$ ). Compounds to be studied were added at the appropriate concentrations. Each concentration was tested in triplicate in the wells. The compounds to be added were first solubilized in medium containing DMSO such that the concentration of DMSO in each well would not exceed $0.2 \%$. The same amount of DMSO was added in the case of cell-based studies. The incubation was continued for $48 \mathrm{~h}$. Upon completion of incubation with the compounds, the drug-containing medium was removed and $200 \mu \mathrm{L}$ of fresh medium was added to each well followed by treatment with $20 \mu \mathrm{L}$ of 1 $\mathrm{mg} \mathrm{mL}^{-1}$ MTT in $1 \times$ phosphate-buffered saline (PBS) (pH 7.2). After incubation for $3 \mathrm{~h}$ with a MTT solution at $37{ }^{\circ} \mathrm{C}$, medium was removed and resulting formazan crystals were dissolved in DMSO $(200 \mu \mathrm{L})$. The growth inhibition of cells was analyzed by measuring the absorbance of the drug-treated wells with respect to untreated ones at $595 \mathrm{~nm}$ using a SpectraMax M2e plate reader. $\mathrm{IC}_{50}$ values (drug concentrations responsible for $50 \%$ cell growth inhibition) were calculated by fitting nonlinear curves in GraphPad Prism 5 version 5.03 , using a variable slope model constructed by plotting the cell viability (percent) versus the log of drug concentration (micromolar) (Figures S25-S28). IC $_{50}$ values were calculated by nonlinear four-parameter curve fitting in a dose-response inhibition-variable slope model using GraphPad Prism. The data presented here are means of at least three independent experiments; in a single experiment, each concentration was assayed in triplicate.

\section{Cell Cycle Arrest}

MDA-MB-231 cells $\left(5 \times 10^{5}\right.$ cells per plate) were grown in a $100 \mathrm{~mm}$ sterile cell culture Petri dish suspended in $5 \mathrm{~mL}$ of DMEM-F12 under previously described culturing condition. After $48 \mathrm{~h}$, medium was removed followed by addition of fresh medium. Appropriate concentrations of the compound solutions were added and incubated under the same condition described above. After being exposed to the drug for $24 \mathrm{~h}$, cells were harvested by trypsinization, centrifuged, and washed twice with cold $1 \times$ PBS buffer ( $\mathrm{pH}$ 7.2). Cells were again resuspended in $100 \mu \mathrm{L}$ of cold $1 \times$ PBS buffer and fixed with $70 \%$ aqueous ethanol overnight at $4{ }^{\circ} \mathrm{C}$. DNA staining was done by resuspending the cell pellets in a $1 \times$ PBS solution containing PI $\left(55 \mu \mathrm{g} \mathrm{mL}^{-1}\right)$ and RNaseA $(100 \mu \mathrm{g} \mathrm{mL}-1)$. Cell suspensions were gently mixed and incubated at $37^{\circ} \mathrm{C}$ for $0.5 \mathrm{~h}$. Then samples were analyzed in a BD Biosciences FACS Calibur flow cytometer. 


\section{Detection of Apoptosis: Annexin-V/PE Assay}

Apoptotic cells were detected using the PE-Annexin V and 7-AAD dual staining apoptosis detection kit (BD Pharmingen) by flow cytometry according to the manufacturer's protocol. A total of $5 \times 10^{5}$ MDA-MB-231 cells were seeded into a $100 \mathrm{~mm}$ sterile tissue culture Petri dish using $6 \mathrm{~mL}$ of DMEM/F-12. Then, cells were incubated at $37{ }^{\circ} \mathrm{C}$ in a $5 \%$ carbon dioxide atmosphere for $48 \mathrm{~h}$. Subsequently, the medium was changed and cells were treated with different concentrations of drug solutions of $\mathbf{1}$ and $\mathbf{3}$ for $24 \mathrm{~h}$. Cells were then harvested with cold $1 \times$ PBS containing $0.1 \mathrm{mM}$ EDTA and subsequently washed twice with cold $1 \times$ PBS and finally resuspended in Annexin V binding buffer. Cells were then incubated with both Annexin V-PE and 7-AAD for $15 \mathrm{~min}$ in the dark at $25^{\circ} \mathrm{C}$. Data were analyzed in a BD Biosciences FACS Calibur flow cytometer within $1 \mathrm{~h}$ of sample preparation.

\section{Detection of Mitochondrial Membrane Potential Alteration by JC-1}

Investigation of the change in mitochondrial transmembrane potential (MMP, $\Delta \Psi_{\mathrm{m}}$ ) was determined using flow cytometry after staining live cells with JC-1. A total of $1 \times 10^{6} \mathrm{MDA}-$ MB-231 cells were seeded in a $100 \mathrm{~mm}$ Petri dish. After incubation for $48 \mathrm{~h}$, medium was removed and the cells were treated with complexes $\mathbf{1}$ and $\mathbf{3}$ using $\mathrm{IC}_{20}$ and $\mathrm{IC}_{50}$ concentrations for $20 \mathrm{~h}$. Cells were then harvested by removing the medium and washed with $1 \times$ PBS. The entire washed sample was collected and centrifuged at $2000 \mathrm{rpm}$ for 4 min. The cells were washed twice with $1 \times$ PBS and resuspended in $1 \times$ PBS supplemented with $10 \%$ FBS. The resultant solution was then incubated with $5 \mu \mathrm{gL}^{-1} \mathrm{JC}-1$ dye for 30 min in the dark. Finally, after the supernatant had been removed, the cells were suspended in $1 \times$ PBS and analyzed in a BD Bioscience FACS Calibur flow cytometer by measuring the red and green fluorescence intensities.

\section{Caspase 3 Activation Assay}

Activation of caspase 3 due to complex treatment was investigated against MDA-MB-231 using the caspase 3 colorimetric detection kit (Sigma). The manufacturer's protocol was followed throughout the assay. In brief, $5 \times 10^{5}$ MDA-MB-231 cells were first seeded in a $100 \mathrm{~mm}$ sterile tissue culture Petri dish for $48 \mathrm{~h}$. Cells were then treated with both $\mathrm{IC}_{20}$ and $\mathrm{IC}_{50}$ concentrations of complexes 1 and 3 for $24 \mathrm{~h}$. The release of $p$-nitroaniline was monitored over time after caspase 3 substrate treatment with the cell lysate. The assay was performed following the 96-well plate method, and data were recorded using an enzymelinked immunosorbent assay plate reader at $405 \mathrm{~nm}$. A standard curve was drawn using a known concentration of $p \mathrm{NA}$ ( $p$-nitroaniline) to estimate the amount of $p \mathrm{NA}$ released by caspase 3.

\section{Docking Studies}

Molecular modeling was performed using GOLD (Genetic Optimization for Ligand Docking) Suite (version 5.4.1) software. GOLD generally adopts the genetic algorithm to dock molecules into protein (macromolecule) active sites. The GOLD score was used as a search algorithmic function for more effective complexes. A higher GOLD score fitness value indicates a better binding interaction in the binding site of the protein. Inhibitor (colchicine)-bound tubulin protein [Protein Data Bank (PDB) entry 1SAO] was used to dock 
the complexes. For receptor preparation, PDB entry $1 \mathrm{SAO}$ was first downloaded from the PDB. The protein was then optimized and energy minimized by applying the OPLS 2005 force field by the protein preparation utility in Maestro Suite 2016-1 in Maestro (Schrödinger Suite 2016-1 Protein Preparation Wizard, Epik, Schrödinger, LLC, New York, NY, 2016; Impact, Schrödinger, LLC, New York, NY, 2016; Prime, Schrödinger, LLC, New York, NY, 2016). This optimized protein was used in the GOLD suite, and the bound inhibitor was extracted. The complexes to be docked were first optimized using Gaussian 09 software via density functional theory (DFT) with the B3LYP functional and 6-31G(d) basis set for $\mathrm{C}, \mathrm{H}, \mathrm{N}$, and $\mathrm{O}$ and sdd basis set for the $\mathrm{Ru}^{\mathrm{II}}$ center and halides. Orbitals were defined as unrestricted during calculations. The conductor-like polarizable continuum model (CPCM) was used with water as the solvent. Known inhibitor colchicine, which was extracted from the active site of $1 \mathrm{SAO}$, was used as is to revalidate the docking study and to compare the affinity with those of other complexes. The optimized protein structure was used in the GOLD Docking Wizard to add necessary hydrogen. The active site was defined using the colchicine binding site and within $6 \AA$ of its center. The binding sphere was large enough to cover the entire active site of the $a$ and $\beta$ tubulin interface.

\section{Effect on Tubulin Polymerization}

A total of $5 \times 10^{4}$ MDA-MB-231 cells were seeded over glass coverslips (Corning Life Sciences) for $48 \mathrm{~h}$. Cells were then treated with complexes $\mathbf{1}$ and $\mathbf{3}$ at $\mathrm{IC}_{20}$ and $\mathrm{IC}_{50}$ doses for $12 \mathrm{~h}$. Cisplatin $(50 \mu \mathrm{M})$ was also treated for $12 \mathrm{~h}$, for use as a negative control, and colchicine $(100 \mathrm{nM})$ was used as the positive control. After $12 \mathrm{~h}$, media containing drugs were removed and washed with $1 \times$ PBS. Cells were then fixed with $4 \%(\mathrm{v} / \mathrm{v})$ paraformaldehyde for $10 \mathrm{~min}$ and subsequently quenched with $100 \mathrm{mM}$ glycine. After being washed three times with $1 \times$ PBS, cells were blocked with $3 \%(\mathrm{w} / \mathrm{v})$ bovine serum albumin (BSA) in PBS containing $0.1 \%$ Tween 20 (PBST) for $20 \mathrm{~min}$ at room temperature. After the BSA had been removed, cells were incubated with the primary antibody against $a$-tubulin (anti- $a$ tubulin antibody, EP1332Y, rabbit monoclonal microtubulin marker) in a 1:400 dilution for $2 \mathrm{~h}$, followed by washing three times with $1 \times$ PBST and $1 \times$ PBS. Secondary antibody incubation was done with goat antirabbit IgG H\&L (AlexaFluor 488) in 1:1000 dilutions for $2 \mathrm{~h}$ in the dark at room temperature. After being washed with PBST and PBS, cells were mounted on slides for imaging using the Fluoroshield mounting medium containing DAPI. The emission of AlexaFluor $488\left(\lambda_{\max }=520 \mathrm{~nm}\right)$ was used to visualize the microtubular network within the cells. The DAPI enabled the visualization of the nucleus. All images were taken with a Leica SP8 confocal microscope with a $63 \times$ objective.

\section{Results and Discussion}

The $\mathrm{N}-\mathrm{O}$ chelating ligands (L1-L4) were synthesized by refluxing the respective amines and aldehydes in $\mathrm{MeOH}$ using the literature procedure ${ }^{53,54}$ with slight modifications. $\mathrm{Ru}$ -arene complexes 1-4 were synthesized in high yields by stirring the respective ligands with an equivalent amount of $\mathrm{KOH}$, followed by addition of $\left[\mathrm{Ru}^{\mathrm{II}}\left(\eta^{6}-p \text {-cym }\right) \mathrm{Cl}_{2}\right]_{2}$ in degassed $\mathrm{MeOH}$ at $50{ }^{\circ} \mathrm{C}$ for $12 \mathrm{~h}$, as shown in Scheme 1 . The isolated bulk product was obtained by column chromatography in neutral alumina. All complexes herein are reported for the first time and well characterized by ${ }^{1} \mathrm{H}$ NMR, ${ }^{13} \mathrm{C}$ NMR, ESI-HRMS, FT-IR, and UV-vis 
analysis. The bulk purity was confirmed by elemental analysis. UV data showed peaks at approximately $275-295 \mathrm{~nm}$ for all of the complexes, which corresponds to the $\pi-\pi^{*}$ transition and a weak peak around $405-420 \mathrm{~nm}$ that corresponds to metal to ligand charge transfer.

\section{X-ray Crystallography}

A suitable single crystal of each complex was obtained from a methanolic solution by slow evaporation. Complex 1 crystallizes in a monoclinic system with space group $P 21 / c$, whereas complexes $\mathbf{3}$ and $\mathbf{4}$ crystallize with a triclinic system in space group $P$ (Table S1). The single-crystal structure of each complex showed a chelating $\mathrm{N}-\mathrm{O}$ coordination from the bidentate Schiff base ligand and a monodentate coordination by a chloride (Figure 2). The fourth position was occupied by one $p$-cymene ring that directly formed an $\eta^{6}$ bond with the ruthenium center. In complex $\mathbf{1}$, each unit cell contains four complexes, whereas there are two complex moieties in $\mathbf{3}$ and $\mathbf{4}$. Some important bond angles and bond distances are listed in Tables 1 and 2. The $\mathrm{Ru}-\mathrm{C}$ bond lengths of the $p$-cymene range from $\sim 2.16$ to $\sim 2.20 \AA$. The $\mathrm{Ru}-\mathrm{O}$ bond distances in complexes $\mathbf{1}, \mathbf{3}$, and $\mathbf{4}$ are in the range of $2.06-2.08 \AA$. The $\mathrm{Ru}$ $-\mathrm{Cl}$ bond distance in the complexes ranges between $\sim 2.42$ and $\sim 2.45 \AA$ (Table 1). The average $\mathrm{O}-\mathrm{Ru}-\mathrm{N}, \mathrm{Cl}-\mathrm{Ru}-\mathrm{N}$, and $\mathrm{O}-\mathrm{Ru}-\mathrm{Cl}$ bond angles are $\sim 88^{\circ}, \sim 84^{\circ}$, and $\sim 86^{\circ}$, respectively (Table 2). Intermolecular weak H-bonding interaction between the metalcoordinated $\mathrm{Cl}$ and aromatic hydrogen of a $p$-cym was observed for $\mathbf{1}$ and $\mathbf{3}$ due to presence of the interacting atoms within the range of 3.2-3.5 $\AA$ (D...A) with a $\angle \mathrm{D}-\mathrm{H}$...A of approximately $140-144^{\circ}$. Another weak H-bond was observed between the Ru-coordinated $\mathrm{O}$ and $\mathrm{H}$ atom of an aromatic ring of $p$-cym with a $\angle \mathrm{D}-\mathrm{H}$...A of approximately $167^{\circ}$. In 4, the $\mathrm{H}$-bonding interaction distance is $3.55 \AA$ and the $\angle \mathrm{D}-\mathrm{H}$...A is approximately $165^{\circ}$ (Figure S18). An oxygen atom of a methoxy group and the Ru-coordinated $\mathrm{O}$ from one complex form bifurcated H-bonds $(\sim 3.32 \AA)$ with an aromatic hydrogen of the $p$-cym ring from another complex with angles (D-H...A) of $153^{\circ}$ and $131^{\circ}$, respectively (Figure S18). A moderate $\pi \ldots \pi$ stacking interaction $(\sim 3.8 \AA)$ between the $p$-cymene motifs of two adjacent complex molecules was observed for complex 3 (Figure S19), whereas for complex 4 , a weak $\pi \ldots \pi$ stacking was observed between two neighboring $o$-vanillin motifs in a unit cell (Figure S19).

\section{Molecular Docking Study}

Combretastatin and colchicine have the same binding site between $a$ and $\beta$ chains of tubulin to inhibit their polymerization, thus disrupting the microtubule network. From the literature reports, it seems that the TMP motif is a crucial one to inhibit tubulin polymerization and present in many tubulin polymerization inhibitors, viz., combretastatin and colchicine. Among our ligands, the strongest resemblance to combretastatin and colchicine was borne by $\mathbf{L} \mathbf{1}$ and $\mathbf{L} \mathbf{3}$ and their corresponding complexes 1 and 3, containing the TMP motif. Hence, $\mathbf{L 1}, \mathbf{L 3}, \mathbf{1}$, and $\mathbf{3}$ were chosen for the docking experiments against $a$ and $\beta$ tubulin assembly (PDB entry 1SAO). Colchicine was taken to compare the docking affinity of the compounds. A higher GOLD score indicates a better binding interaction of a molecule with the protein active site. Docking studies with $\mathbf{1}$ and $\mathbf{3}$ suggest that they bind to the colchicine binding site of the $a$ and $\beta$ tubulin assembly, and GOLD score values (Table S2) indicate that the binding 
affinity of 1 (GOLD score of 48.6) is higher than that of 3 (GOLD score of 40.5). On the other hand, the docking of ligands L1 (GOLD score of 49.9) and L3 (GOLD score of 52.9) to the same protein structure displays stronger interactions of the ligands themselves, indicating their suitability in the design. The noncovalent interaction of $\mathbf{1}$ is mainly through hydrogen bonding of the $p$-OMe group with the side-chain $-\mathrm{NH}_{2}$ of Lys 254 and the $-\mathrm{CONH}_{2}$ of $\mathrm{Gln} 11$ of the protein. In 3, the $m$-OMe group is hydrogen bonded with the carboxylate of the Glu183 residue (Figure S20). Thus, in the TMP motif-containing complexes, the salicylaldehyde-based ligand showed better interaction, leading to a higher affinity of $\mathbf{1}$ as per the docking studies. The docking studies show good interaction between the compounds and the tubulin indicating the ability of the compounds to interact with the protein, but the actual inhibition will depend on other important factors, viz., the stability of the molecules in the culture media, the ability to enter cells, and the flexibility of the molecule inside the protein structure. Hence, we investigated the stability of the ligands and complexes in aqueous solutions and probed their lipophilicity.

\section{Stability in an Aqueous Solution}

To understand the of fate the ruthenium complexes under physiological conditions, we studied the stability of the complexes using either DMF- $d_{7}$ or DMSO- $d_{6}$ with $20 \mathrm{mM}$ phosphate buffer $(\mathrm{pH} 7.4,4 \mathrm{mM} \mathrm{NaCl})$ in a 1:9 (v/v) ratio. Stability studies showed that complexes 1 and $\mathbf{2}$ were hydrolyzed within the first $5 \mathrm{~min}$ completely to produce solely aquated species. The immediate formation of the aquated species was confirmed by incubating the sample with $\mathrm{AgNO}_{3}$, which yielded the precipitation of $\mathrm{AgCl}$, but there was no change in the chemical shift observed by ${ }^{1} \mathrm{H}$ NMR. Hence, we concluded that the complexes may have hydrolyzed very fast. The hydrolyzed aquated species is stable for at least $24 \mathrm{~h}$ (Figure 3 and Figures S21 and S22). A similar result was obtained for 3 (Figure S23). Because the stabilities of the complexes were similar, their cytotoxicity would be dependent on the amount of interaction of the complexes with the desired target if the lipophilicities are similar.

The stability of the ligands was also monitored by ${ }^{1} \mathrm{H}$ NMR using a DMSO- $d_{6} /$ phosphate buffer mixture $[3: 7(\mathrm{v} / \mathrm{v})]$. It was observed that due to the presence of the hydrolyzable imine bond both ligands ( $\mathbf{L} 1$ and $\mathbf{L 3}$ ) were hydrolyzed very quickly (almost $80 \%$ hydrolysis within $12 \mathrm{~h}$ ) into corresponding amine and aldehyde (Figure S24). The complexes of the same were found to be stable as discussed above, suggesting that the complexation increased the aqueous stability of the ligands.

\section{Determination of Distribution Coefficients}

Lipophilicity is considered to be an indication of understanding the cellular uptake capability of a compound. Hence, lipophilicity is an important parameter while studying cytotoxic efficacy. The distribution coefficient values for ligands (L1-L4) as well as complexes 1-4 in octanol/water systems were determined. The values of $\log D$ for the ligands vary from 2.5 to 4 , showing a wide spectrum of lipophilicity and indicating the low water solubility of the ligands. Complexation increased the water solubility and decreased the $\log D$ to approximately $0.18-0.4$ (Figure 4). The $\log D$ values of new pharmacophores in the Comprehensive Medicinal Chemistry database range from -0.4 to $5.6 .^{58} \mathrm{It}$ is 
encouraging to find that the $\log D$ values for the ligands and complexes 1-4 are within the range of new pharmacophores as shown by the database. In addition, the $\log D$ values are quite similar, suggesting that the activity would be mostly dependent only on the interaction of the complexes with their targets due to the variation mostly in the number of methoxy groups and the overall geometry of the complex.

\section{In Vitro Cytotoxicity}

Cytotoxicities of all four ligands (L1-L4) and metal complexes (1-4) were tested in three different cancer cell lines under normoxic conditions by the MTT assay. The cell lines chosen for this purpose were human pancreatic carcinoma (MIA PaCa-2), triple negative human metastatic breast adenocarcinoma (MDA-MB-231), and hepatocellular carcinoma (Hep G2). Data obtained are listed in Table 3. Triple negative breast cancer, pancreatic carcinoma, and liver carcinoma are difficult to cure; hence, these cell lines have been chosen. In particular, triple negative breast cancer MDA-MB-231 is one of the most difficult to treat and has a poor response rate due to absence of three main targeting receptors (estrogen, progesterone, and HER2). Thus, the treatment of metastatic MDA-MB-231 almost solely depends on chemotherapy and has a high relapse rate with existing drugs. The MIA PaCa- 2 cell line was chosen because it is known to be an aggressive pancreatic cancer with high tumorigenicity ${ }^{59}$ and does not express a detectable amount of carcino embryonic antigen, thus making detection difficult. ${ }^{60}$ The in vitro studies showed that the ligands are nontoxic but complexation increased their solubility and toxicity. The docking studies (Figure S20) did, however, suggest that the ligands should be toxic but did not take into account the stability of the ligands in solution. The stability of the free ligands is poor in a buffer solution as depicted by $\sim 80 \%$ degradation of $\mathbf{L 1}$ and $\mathbf{L 3}$, to corresponding amine and aldehyde, during a $12 \mathrm{~h}$ incubation period (Figure S24). The ligands dissociate to their respective amine and aldehyde (Figure S24). In addition, due to the high lipophilicity of the ligands, it is also possible that most of the intact ligands are stuck at the cell membrane. The metal complexation imparts stability to the ligand and increases the hydrophilicity, allowing the complexes to enter the cell cytoplasm thus enhancing their cytotoxicity.

$\mathrm{IC}_{50}$ values of all four complexes range between 10 and $25 \mu \mathrm{M}$ (Table 3). Complex $\mathbf{1}$ is the most toxic and is approximately 3 times more potent than cisplatin (a drug used in treatment of TNBC) $)^{61}$ against MDA-MB-231 and MIA PaCa-2 under the same testing conditions.

When 1 and $\mathbf{3}$ were tested in the MDA-MB-231 cell line under hypoxic conditions to check if there was any deactivation under hypoxia, which is known to happen for many drugs, ${ }^{62,63}$ it was found that the cytotoxicity remained unaltered. The anticancer activities of the salicylaldimino derivatives are higher than those of $o$-vanillinaldimino analogues as is evident from Table 3 on going from 1 to 4 .

\section{Effect on Tubulin Polymerization}

The in vitro toxicity profile showed that complex $\mathbf{1}$ is the most toxic among all of the complexes and $\mathbf{3}$ is less toxic than $\mathbf{1}$, which also corelates with the docking study. However, there is an extra methoxy group present in $\mathbf{3}$ compared to $\mathbf{1}$ that hence makes it more resemble the combretastatin structure. Therefore, $\mathbf{1}$ and $\mathbf{3}$ were selected to evaluate their effect on the disruption of the microtubule network in the MDA-MB-231 cells. Colchicine 
was taken as a positive control because it is known to inhibit tubulin polymerization, whereas cisplatin was taken as a negative control because it is a DNA cross-linking agent. With regard to cisplatin, we would like the readers to note that there are some discrete reports indicating the potency of cisplatin to interact with tubulin and disrupt polymerization at significantly high dosages, although no cellular studies have been reported. However, in our cellular studies when we used $50 \mu \mathrm{M}$ CDDP and treated MDA-MB-231 cells with them for $12 \mathrm{~h}$, we did not observe any disruption of the microtubule formation as evidenced from Figure 5C.

The control cells without drug treatment exhibited a normal filamentous microtubule array (green fluorescence) (Figure 5A) and so did the cisplatin-treated cells (Figure 5C). However, the effect of cisplatin on the nucleus could be observed in some portions (Figure S29). The cells treated with colchicine (positive control) exhibited microtubule network damage (Figure 5B). When cells were treated with complexes $\mathbf{1}$ and $\mathbf{3}$ at $\mathrm{IC}_{50}$ doses (Figure 5D,E), they exhibited disruption of the microtubule networks leading to deformation similar to that observed for colchicine. Even at only $\mathrm{IC}_{20}$ dosages of $\mathbf{1}$ and $\mathbf{3}$, the disruption of the microtubule network was evident (Figure S29). Thus, $\mathbf{1}$ and $\mathbf{3}$ induced disruption of the microtubule in a dose-dependent manner, indicating tubulin polymerization was inhibited by these complexes in MDA-MB-231 cells.

The inhibition effect became more apparent when the data were quantified (Figure 6). It was done by averaging the perimeter of the microtubule network for at least 10 treated cells versus the same number of untreated cells from a control. The relative perimeter (i.e., treated vs control) was plotted, and better dose responses of $\mathbf{1}$ over $\mathbf{3}$ were observed.

\section{Pathways of Cell Killing}

The compounds under investigation were half-sandwich complexes of $\mathrm{Ru}^{\mathrm{II}}$, many of which exhibit excellent interactions with DNA bases. Hence, in spite of the tubulin network disrupting ability, these complexes were probed for their ability to bind 9-ethyl guanine, a model nucleobase, using ESI-MS. Complexes were treated with 5 molar equivalents of 9EtG in a 1:9 (v/v) mixture of $\mathrm{MeOH}$ and $5 \mathrm{mM}$ phosphate buffer ( $\mathrm{pH} 7.4$, containing $4 \mathrm{mM}$ $\mathrm{NaCl}$ ) and studied in ESI-MS. The ESI-MS data did not show any binding even after incubation for $24 \mathrm{~h}$ (Figures S30-S37). In general, any 9-EtG adduct formation is prominently found in the resultant spectrum for this $p$-cymene class of $\mathrm{Ru}^{\mathrm{II}}$ complexes, as reported previously. ${ }^{23}$ These indicate that DNA may not be the prime target for these classes of compounds; rather, they may noncovalently interact with the interface of the $a$ and $\beta$ tubulin during the mitotic phase, at the colchicine binding site.

Certain half-sandwich $\mathrm{Ru}^{\mathrm{II}}-p$-cymene complexes are also known to enhance ROS production or concentration, which actively helps apoptosis by inducing oxidative stress in cells. ROS may be generated by these $\mathrm{Ru}^{\mathrm{II}}-p$-cymene complexes due to their ability to disrupt the intracellular redox balance by catalytic conversion of intracellular NADH to $\mathrm{NAD}^{+.30,64}$ Complexes 1 and 3 were treated with NADH [1:9 (v/v) MeOH and water containing $4 \mathrm{mM} \mathrm{NaCl}$ ], and the absorption at $\lambda_{\max }$ values of 260 and $340 \mathrm{~nm}$ was monitored for $6 \mathrm{~h}$ (Figure S38). There was almost no change observed, and it was rather similar to the control experiment. This suggested that the complexes were not converting 
$\mathrm{NADH}$ to $\mathrm{NAD}^{+}$. To investigate, if there was any other process involved in the enhancement of ROS by the complexes, we performed an in vitro cellular assay using $\mathrm{IC}_{20}$ and $\mathrm{IC}_{50}$ dosages of 1 and $\mathbf{3}$ in the MDA-MB-231 cell line. After being incubated for $12 \mathrm{~h}$, the cells were stained by DCFHDA and analyzed by flow cytometry for the ROS population. The data showed that there is no increase in the ROS level upon treatment, suggesting that these complexes do not enhance ROS production in cells (Figure S39).

The studies with $\mathbf{1}$ and $\mathbf{3}$ showed that the complexes inhibited tubulin polymerization and did not enhance ROS production. If the disruption of the microtubule network is the pathway of cell killing, then the cell cycle arrest should occur in the mitotic phase. Complex $\mathbf{1}$ was thus probed for cell cycle arrest in the MDA-MB-231 cell line by flow cytometry using a propidium iodide assay with two concentrations ( 8 and $12 \mu \mathrm{M})$. It was found that with increasing concentrations of $\mathbf{1}$, the population of cells arrested at the G2/M phase increased (Figure 7A and Figure S40). This further supported the idea that the cytotoxicity of the complexes is mediated via disruption of the microtubule network in the mitotic phase. Both $\mathbf{1}$ and $\mathbf{3}$ induced apoptosis as per the Annexin-V/PE and 7AAD double-staining assay in MDA-MB-231 cells. The $\mathrm{IC}_{50}$ as well as the sub-IC $\mathrm{IC}_{50}$ dose showed that cell killing occurs through apoptosis. 1 induced $\sim 60 \%$ and $\sim 74 \%$ of apoptosis at $\mathrm{IC}_{20}$ and $\mathrm{IC}_{50}$ dosages, respectively, whereas 3 induced $\sim 63 \%$ and $\sim 70 \%$ apoptosis at $\mathrm{IC}_{20}$ and $\mathrm{IC}_{50}$ dosages, respectively (compared to 7\% in control) (Figure 7B and Figure S41). The late apoptotic stage cells become stained with both Annexin-V and 7-AAD; the early apoptotic population becomes stained with only Annexin-V, and dead cells are stained with only 7-AAD, thus allowing the detection.

It is important to know if the apoptosis is induced through extrinsic or intrinsic pathways or both are involved. The intrinsic pathway is regulated via mitochondria and may be monitored by the change in the mitochondrial membrane potential (MMP, $\Delta \Psi_{\mathrm{m}}$ ) using the fluorescent dye JC-1 using flow cytometry. JC-1 dye in aggregated form emits red fluorescence at a $\lambda_{\max }$ of $590 \mathrm{~nm}$, but when the mitochondrial membrane depolarizes, it stabilizes the monomeric form of JC-1 that emits a green fluorescence at a $\lambda_{\max }$ of $550 \mathrm{~nm}$. MDA-MB-231 cells treated with the $\mathrm{IC}_{20}$ or $\mathrm{IC}_{50}$ concentration of $\mathbf{1}$ and $\mathbf{3}$ for 18 h showed an increase in the green fluorescence intensity in a dose-dependent manner, suggesting the intrinsic pathway may be mostly involved in apoptosis (Figure 7C and Figure S42). Apoptosis was also further confirmed by the release of caspase 3 . The mitochondrial membrane potential change leads to the release of cytochrome $c$, which activates caspase 9 (initiator caspase) that ultimately cascades to activate caspase 3 (effector caspase), leading to apoptotic cell death after proteolytic cleavage of a series of cellular targets. MDA-MB-231 cells treated with $\mathrm{IC}_{20}$ and $\mathrm{IC}_{50}$ concentrations of $\mathbf{1}$ and $\mathbf{3}$ showed release of free $p \mathrm{NA}$ in a dose-dependent manner (Figure 7D), from the active caspase 3 substrate (Ac-DEVD-pNA) thus further emphasizing the apoptotic pathway.

\section{Conclusion}

The N-O chelating half-sandwich $\mathrm{Ru}^{\mathrm{II}}-p$-cymene complexes containing di- and trimethoxyphenyl motifs showed inhibition of tubulin polymerization, thereby disrupting the microtubule network in triple negative metastatic breast cancer MDA-MB-231. The 
complexes exhibited aquation at physiological $\mathrm{pH}$ ( $\mathrm{pH}$ 7.4); the trimethoxyphenylcontaining aquated $\mathrm{Ru}^{\mathrm{II}}-p$-cymene complexes do not bind to the guanine $\mathrm{N}^{7}$, unlike DNAtargeting drugs like cisplatin, nor do they enhance ROS. Complex $\mathbf{1}$ that is most efficient in microtubule network disruption during the mitotic phase is also the most cytotoxic complex in the series and arrests the cell cycle in the G2/M phase, suggesting microtubule network disruption is the major pathway of cytotoxicity. The inhibition described above led to depolarization of the mitochondria, activation of caspase 3, and finally apoptosis.

\section{Supplementary Material}

Refer to Web version on PubMed Central for supplementary material.

\section{Acknowledgments}

The authors earnestly acknowledge CSIR, Government of India, via Project 01(2927)/18/EMR-II. The authors also thank IISER Kolkata for infrastructural and financial support. S.A. thanks UGC. M.M. thanks CSIR. Ruturaj thanks IISER Kolkata. K.P. thanks UGC for research fellowships. A.G. is thankful for the Early Career research Award from SERB, DST, Government of India (ECR/2015/000220), and a Wellcome Trust-DBT India Alliance Fellowship (IA/I/16/1/502369). The authors thank Dr. Supratim Dutta for the microplate reader facility. The authors sincerely thank Mr. Tamal Ghosh for helping with flow cytometry analysis studies.

\section{References}

1. Johnstone TC, Suntharalingam K, Lippard SJ. The Next Generation of Platinum Drugs: Targeted Pt(II) Agents, Nanoparticle Delivery, and Pt(IV) Prodrugs. Chem Rev. 2016; 116:3436-3486. [PubMed: 26865551]

2. Ndagi U, Mhlongo N, Soliman ME. Metal complexes in cancer therapy - an update from drug design perspective. Drug Des, Dev Ther. 2017; 11:599-616.

3. Zeng L, Gupta P, Chen Y, Wang E, Ji L, Chao H, Chen Z-S. The development of anticancer ruthenium(II) complexes: from single molecule compounds to nanomaterials. Chem Soc Rev. 2017; 46:5771-5804. [PubMed: 28654103]

4. Meier-Menches SM, Gerner C, Berger W, Hartinger CG, Keppler BK. Structure-activity relationships for ruthenium and osmium anticancer agents - towards clinical development. Chem Soc Rev. 2018; 47:909-928. [PubMed: 29170783]

5. Thota S, Rodrigues DA, Crans DC, Barreiro EJ. Ru(II) Compounds: Next-Generation Anticancer Metallotherapeutics? J Med Chem. 2018; 61:5805-5821. [PubMed: 29446940]

6. Chitambar CR. Gallium-containing anticancer compounds. Future Med Chem. 2012; 4:1257-1272. [PubMed: 22800370]

7. Timerbaev AR. Advances in developing tris(8-quinolinolato)-gallium(III) as an anticancer drug: critical appraisal and prospects. Metallomics. 2009; 1:193-198. [PubMed: 21305117]

8. Trondl R, Heffeter P, Kowol CR, Jakupec MA, Berger W, Keppler BK. NKP-1339, the first ruthenium-based anticancer drug on the edge to clinical application. Chem Sci. 2014; 5:2925-2932.

9. Aird RE, Cummings J, Ritchie AA, Muir M, Morris RE, Chen H, Sadler PJ, Jodrell DI. In vitro and in vivo activity and cross resistance profiles of novel ruthenium (II) organometallic arene complexes in human ovarian cancer. Br J Cancer. 2002; 86:1652-1657. [PubMed: 12085218]

10. Han Ang W, Dyson PJ. Classical and non-classical ruthenium-based anticancer drugs: towards targeted chemotherapy. Eur J Inorg Chem. 2006; 2006:4003-4018.

11. Bruijnincx PCA, Sadler PJ. New trends for metal complexes with anticancer activity. Curr Opin Chem Biol. 2008; 12:197-206. [PubMed: 18155674]

12. Bergamo A, Gaiddon C, Schellens JHM, Beijnen JH, Sava G. Approaching tumour therapy beyond platinum drugs: Status of the art and perspectives of ruthenium drug candidates. J Inorg Biochem. 2012; 106:90-99. [PubMed: 22112845] 
13. Gianferrara T, Bergamo A, Bratsos I, Milani B, Spagnul C, Sava G, Alessio E. RutheniumPorphyrin Conjugates with Cytotoxic and Phototoxic Antitumor Activity. J Med Chem. 2010; 53:4678-4690. [PubMed: 20491441]

14. Bergamo A, Gava B, Alessio E, Mestroni G, Serli B, Cocchietto M, Zorzet S, Sava G. Rutheniumbased NAMI-A type complexes with in vivo selective metastasis reduction and in vitro invasion inhibition unrelated to cell cytotoxicity. Int J Oncol. 2002; 21:1331-1338. [PubMed: 12429985]

15. Kapitza S, Pongratz M, Jakupec MA, Heffeter P, Berger W, Lackinger L, Keppler BK, Marian B. Heterocyclic complexes of ruthenium(III) induce apoptosis in colorectal carcinoma cells. J Cancer Res Clin Oncol. 2005; 131:101-110. [PubMed: 15503135]

16. Leijen S, Burgers SA, Baas P, Pluim D, Tibben M, van Werkhoven E, Alessio E, Sava G, Beijnen JH, Schellens JHM. Phase I/II study with ruthenium compound NAMI-A and gemcitabine in patients with non-small cell lung cancer after first line therapy. Invest New Drugs. 2015; 33:201214. [PubMed: 25344453]

17. Alessio E, Messori L. The deceptively similar Ruthenium(III) drug candidates KP1019 and NAMIA have different actions. What did we learn in the past 30 years? Met Ions Life Sci. 2018; 18:141170.

18. Peacock AFA, Sadler PJ. Medicinal organometallic chemistry: designing metal arene complexes as anticancer agents. Chem - Asian J. 2008; 3:1890-1899. [PubMed: 18712745]

19. Wang F, Chen H, Parkinson JA, Murdoch PdS, Sadler PJ. Reactions of a Ruthenium(II) Arene Antitumor Complex with Cysteine and Methionine. Inorg Chem. 2002; 41:4509-4523. [PubMed: 12184769]

20. Chen H, Parkinson JA, Morris RE, Sadler PJ. Highly Selective Binding of Organometallic Ruthenium Ethylenediamine Complexes to Nucleic Acids: Novel Recognition Mechanisms. J Am Chem Soc. 2003; 125:173-186. [PubMed: 12515520]

21. Chen H, Parkinson JA, Parsons S, Coxall RA, Gould RO, Sadler PJ. Organometallic Ruthenium(II) Diamine Anticancer Complexes: Arene-Nucleobase Stacking and Stereospecific HydrogenBonding in Guanine Adducts. J Am Chem Soc. 2002; 124:3064-3082. [PubMed: 11902898]

22. Romero-Canelon I, Salassa L, Sadler PJ. The Contrasting Activity of Iodido versus Chlorido Ruthenium and Osmium Arene Azo- and Imino-pyridine Anticancer Complexes: Control of Cell Selectivity, Cross-Resistance, p53 Dependence, and Apoptosis Pathway. J Med Chem. 2013; 56:1291-1300. [PubMed: 23368735]

23. Sarkar A, Acharya S, Khushvant K, Purkait K, Mukherjee A. Cytotoxic RuII-p-cymene complexes of an anthraimidazoledione: halide dependent solution stability, reactivity and resistance to hypoxia deactivation. Dalton Trans. 2019; 48:7187-7197. [PubMed: 30601545]

24. Morris RE, Aird RE, del Socorro Murdoch P, Chen H, Cummings J, Hughes ND, Parsons S, Parkin A, Boyd G, Jodrell DI, Sadler PJ. Inhibition of Cancer Cell Growth by Ruthenium(II) Arene Complexes. J Med Chem. 2001; 44:3616-3621. [PubMed: 11606126]

25. Wang F, Habtemariam A, van der Geer EPL, Fernandez R, Melchart M, Deeth RJ, Aird R, Guichard S, Fabbiani FPA, Lozano-Casal P, Oswald IDH, et al. Controlling ligand substitution reactions of organometallic complexes: Tuning cancer cell cytotoxicity. Proc Natl Acad Sci USA. 2005; 102:18269-18274. [PubMed: 16352726]

26. Peacock AFA, Habtemariam A, Fernandez R, Walland V, Fabbiani FPA, Parsons S, Aird RE, Jodrell DI, Sadler PJ. Tuning the Reactivity of Osmium(II) and Ruthenium(II) Arene Complexes under Physiological Conditions. J Am Chem Soc. 2006; 128:1739-1748. [PubMed: 16448150]

27. Pelletier F, Comte V, Massard A, Wenzel M, Toulot S, Richard P, Picquet M, Le Gendre P, Zava O, Edafe F, Casini A, et al. Development of Bimetallic Titanocene-Ruthenium-Arene Complexes As Anticancer Agents: Relationships between Structural and Biological Properties. J Med Chem. 2010; 53:6923-6933. [PubMed: 20822096]

28. Gill MR, Cecchin D, Walker MG, Mulla RS, Battaglia G, Smythe C, Thomas JA. Targeting the endoplasmic reticulum with a membrane-interactive luminescent ruthenium(ii) polypyridyl complex. Chem Sci. 2013; 4:4512-4519. [PubMed: 25580209]

29. Zou T, Lok C-N, Fung YME, Che C-M. Luminescent organoplatinum(II) complexes containing bis(N-heterocyclic carbene) ligands selectively target the endoplasmic reticulum and induce potent photo-toxicity. Chem Commun. 2013; 49:5423-5425. 
30. Tian Z, Li J, Zhang S, Xu Z, Yang Y, Kong D, Zhang H, Ge X, Zhang J, Liu Z. Lysosome-Targeted Chemotherapeutics: Half-Sandwich Ruthenium(II) Complexes That Are Selectively Toxic to Cancer Cells. Inorg Chem. 2018; 57:10498-10502. [PubMed: 30118214]

31. Li J, Tian Z, Xu Z, Zhang S, Feng Y, Zhang L, Liu Z. Highly potent half-sandwich iridium and ruthenium complexes as lysosome-targeted imaging and anticancer agents. Dalton Trans. 2018; 47:15772-15782. [PubMed: 30357192]

32. Jin S, Hao Y, Zhu Z, Muhammad N, Zhang Z, Wang K, Guo Y, Guo Z, Wang X. Impact of Mitochondrion-Targeting Group on the Reactivity and Cytostatic Pathway of Platinum(IV) Complexes. Inorg Chem. 2018; 57:11135-11145. [PubMed: 30117731]

33. Liu J, Chen Y, Li G, Zhang P, Jin C, Zeng L, Ji L, Chao H. Ruthenium(II) polypyridyl complexes as mitochondriatargeted two-photon photodynamic anticancer agents. Biomaterials. 2015; 56:140153. [PubMed: 25934287]

34. Huang X, Huang R, Gou S, Wang Z, Liao Z, Wang H. Combretastatin A-4 Analogue: A DualTargeting and Tubulin Inhibitor Containing Antitumor Pt(IV) Moiety with a Unique Mode of Action. Bioconjugate Chem. 2016; 27:2132-2148.

35. Huang X, Huang R, Gou S, Wang Z, Liao Z, Wang H. Platinum(IV) complexes conjugated with phenstatin analogue as inhibitors of microtubule polymerization and reverser of multidrug resistance. Bioorg Med Chem. 2017; 25:4686-4700. [PubMed: 28728896]

36. Biersack B, Effenberger K, Knauer S, Ocker M, Schobert R. Ru( $\eta 6$-arene) complexes of combretastatin-analogous oxazoles with enhanced anti-tumoral impact. Eur J Med Chem. 2010; 45:4890-4896. [PubMed: 20727621]

37. Honore S, Pasquier E, Braguer D. Understanding microtubule dynamics for improved cancer therapy. Cell Mol Life Sci. 2005; 62:3039-3056. [PubMed: 16314924]

38. Pellegrini F, Budman D. Review: tubulin function, action of antitubulin drugs, and New drug development. Cancer Invest. 2005; 23:264-273. [PubMed: 15948296]

39. Gigant B, Wang C, Ravelli RBG, Roussi F, Steinmetz MO, Curmi PA, Sobel A, Knossow M. Structural basis for the regulation of tubulin by vinblastine. Nature. 2005; 435:519-522. [PubMed: 15917812]

40. Loewe J, Li H, Downing KH, Nogales E. Refined Structure of a $\beta$-Tubulin at $3.5 \AA$ Resolution. J Mol Biol. 2001; 313:1045-1057. [PubMed: 11700061]

41. Mahindroo N, Liou J-P, Chang J-Y, Hsieh H-P. Antitubulin agents for the treatment of cancer - a medicinal chemistry update. Expert Opin Ther Pat. 2006; 16:647-691.

42. Prinz H, Ridder A-K, Vogel K, Boehm KJ, Ivanov I, Ghasemi JB, Aghaee E, Mueller K. NHeterocyclic (4-Phenylpiperazin-1-yl)methanones Derived from Phenoxazine and Phenothiazine as Highly Potent Inhibitors of Tubulin Polymerization. J Med Chem. 2017; 60:749-766. [PubMed: 28045256]

43. Huang X, Huang R, Wang Z, Li L, Gou S, Liao Z, Wang H. Pt(IV) complexes conjugating with chalcone analogue as inhibitors of microtubule polymerization exhibited selective inhibition in human cancer cells. Eur J Med Chem. 2018; 146:435-450. [PubMed: 29407969]

44. Huang X, Hua S, Huang R, Liu Z, Gou S, Wang Z, Liao Z, Wang H. Dual-targeting antitumor hybrids derived from Pt(IV) species and millepachine analogues. Eur J Med Chem. 2018; 148:125. [PubMed: 29448138]

45. Fu Y, Sanchez-Cano C, Soni R, Romero-Canelon I, Hearn JM, Liu Z, Wills M, Sadler PJ. The contrasting catalytic efficiency and cancer cell antiproliferative activity of stereoselective organoruthenium transfer hydrogenation catalysts. Dalton Trans. 2016; 45:8367-8378. [PubMed: 27109147]

46. De Martino G, Edler MC, La Regina G, Coluccia A, Barbera MC, Barrow D, Nicholson RI, Chiosis G, Brancale A, Hamel E, Artico M, et al. New Arylthioindoles: Potent Inhibitors of Tubulin Polymerization. 2. Structure-Activity Relationships and Molecular Modeling Studies. J Med Chem. 2006; 49:947-954. [PubMed: 16451061]

47. Kaur R, Kaur G, Gill RK, Soni R, Bariwal J. Recent developments in tubulin polymerization inhibitors: An overview. Eur J Med Chem. 2014; 87:89-124. [PubMed: 25240869] 
48. Alvarez C, Alvarez R, Corchete P, Perez-Melero C, Peláez R, Medarde M. Exploring the effect of 2,3,4-trimethoxyphenyl moiety as a component of indolephenstatins. Eur J Med Chem. 2010; 45:588-597. [PubMed: 19939521]

49. Brancale A, Silvestri R. Indole, a core nucleus for potent inhibitors of tubulin polymerization. Med Res Rev. 2007; 27:209-238. [PubMed: 16788980]

50. Ray K, Bhattacharyya B, Biswas BB. Role of B-ring of colchicine in its binding to tubulin. J Biol Chem. 1981; 256:6241-4. [PubMed: 7240202]

51. Lu Y, Chen J, Wang J, Li C-M, Ahn S, Barrett CM, Dalton JT, Li W, Miller DD. Design, Synthesis, and Biological Evaluation of Stable Colchicine Binding Site Tubulin Inhibitors as Potential Anticancer Agents. J Med Chem. 2014; 57:7355-7366. [PubMed: 25122533]

52. Bennett MA, Huang TN, Matheson TW, Smith AK, Ittel S, Nickerson W. ( $\eta 6-$ Hexamethylbenzene)ruthenium complexes. Inorg Synth. 2007; 21:74-8.

53. Guillaume KC, Herve Z, Anoubile B, Jacques E. Preparation, spectroscopy, physicochemical properties and $\mathrm{x}$-ray structure analysis of 3,4,5-trimethoxy-N-(2-hydroxybenzylidene)-aniline. E-J Chem. 2009; 6:1103-1108.

54. Aziz AN, Taha M, Ismail NH, Anouar EH, Yousuf S, Jamil W, Awang K, Ahmat N, Khan KM, Kashif SM. Synthesis, crystal structure, DFT studies and evaluation of the antioxidant activity of 3,4-dimethoxybenzenamine Schiff bases. Molecules. 2014; 19:8414-8433. [PubMed: 24950444]

55. Palatinus L, Chapuis G. SUPERFLIP. A computer program for the solution of crystal structures by charge flipping in arbitrary dimensions. J Appl Crystallogr. 2007; 40:786-790.

56. Sheldrick GM. A short history of SHELX. Acta Crystallogr, Sect: A Found Crystallogr. 2008; 64:112-122.

57. Dolomanov OV, Bourhis LJ, Gildea RJ, Howard JAK, Puschmann H. OLEX2: a complete structure solution, refinement and analysis program. J Appl Crystallogr. 2009; 42:339-341.

58. Ghose AK, Viswanadhan VN, Wendoloski JJ. A Knowledge-Based Approach in Designing Combinatorial or Medicinal Chemistry Libraries for Drug Discovery. 1. A Qualitative and Quantitative Characterization of Known Drug Databases. J Comb Chem. 1999; 1:55-68. [PubMed: 10746014]

59. Deer EL, Gonzalez-Hernandez J, Coursen JD, Shea JE, Ngatia J, Scaife CL, Firpo MA, Mulvihill SJ. Phenotype and genotype of pancreatic cancer cell lines. Pancreas. 2010; 39:425-435. [PubMed: 20418756]

60. Kwong W-L, Lam K-Y, Lok C-N, Lai Y-T, Lee P-Y, Che C-M. A Macrocyclic Ruthenium(III) Complex Inhibits Angiogenesis with Down-Regulation of Vascular Endothelial Growth Factor Receptor-2 and Suppresses Tumor Growth In Vivo. Angew Chem Int Ed. 2016; 55:13524-13528.

61. Wahba HA, El-Hadaad HA. Current approaches in treatment of triple-negative breast cancer. Cancer Biol Med. 2015; 12:106-116. [PubMed: 26175926]

62. Strese S, Fryknaes M, Larsson R, Gullbo J. Effects of hypoxia on human cancer cell line chemosensitivity. BMC Cancer. 2013; 13:331. [PubMed: 23829203]

63. Brown JM, Wilson WR. Exploiting tumor hypoxia in cancer treatment. Nat Rev Cancer. 2004; 4:437-447. [PubMed: 15170446]

64. Betanzos-Lara S, Liu Z, Habtemariam A, Pizarro AM, Qamar B, Sadler PJ. Organometallic Ruthenium and Iridium Transfer-Hydrogenation Catalysts Using Coenzyme NADH as a Cofactor. Angew Chem, Int Ed. 2012; 51:3897-3900. 


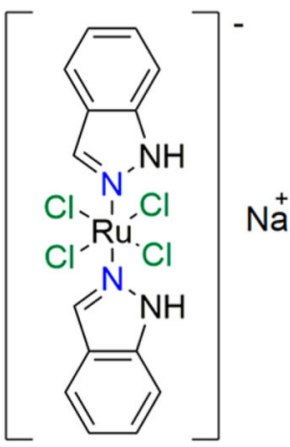

NKP 1339<smiles>COc1cc2c(c(OC)c1OC)-c1ccc(OC)c(=O)cc1[C@@H](NC(C)=O)CC2</smiles>

Colchicine

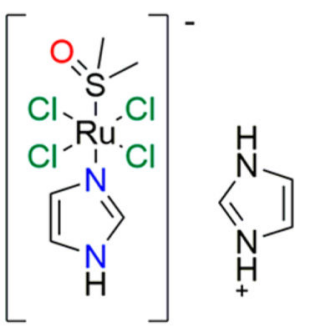

NAMI A

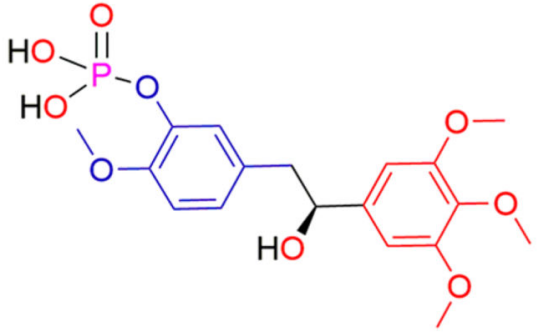

Combretastatin A-4 phosphate<smiles>Cc1ccc(C(C)C)cc1[R1](Cl)(Cl)[Pb]12CN3CN(CN(C3)C1)C2</smiles>

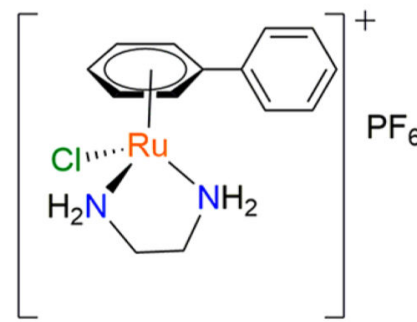

RAPTA-C

RM175

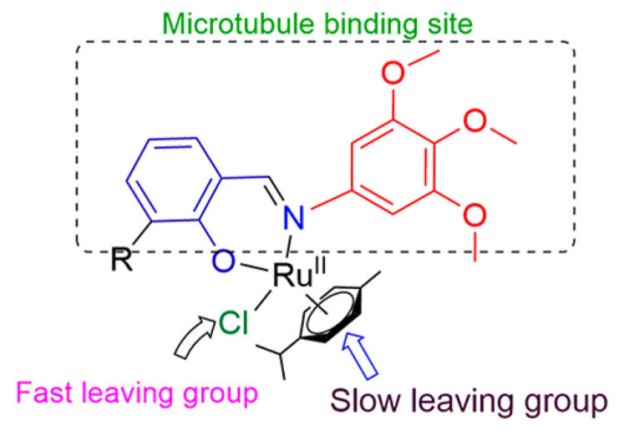

General Representation of Ru" Complexes

Figure 1.

RuIII (NKP1339 and NAMI-A) and half-sandwich Ru ${ }^{\mathrm{II}}$ (RAPTA-C and RM175) anticancer agents, tubulin polymerization inhibitors (colchicine and combretastatin), and a general representation of the $\mathrm{Ru}^{\mathrm{II}}$ complexes studied herein. 

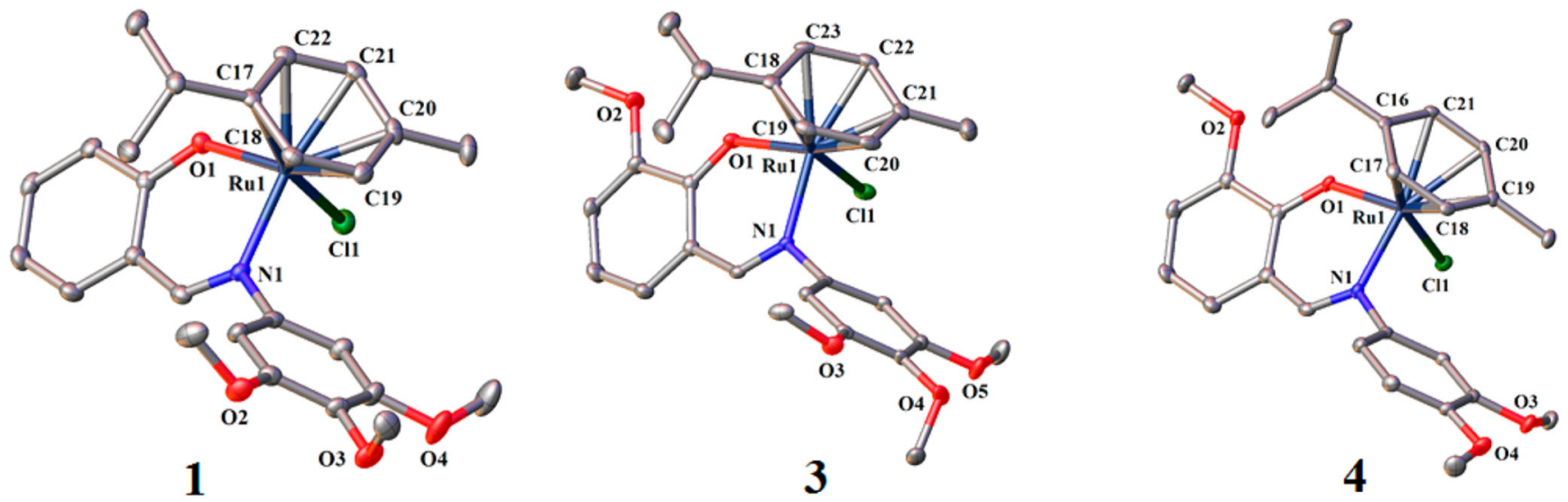

Figure 2.

ORTEP diagrams of complexes $\mathbf{1}, \mathbf{3}$, and $\mathbf{4}$. Thermal ellipsoids are drawn at the $50 \%$ probability level. All hydrogen atoms have been omitted for the sake of clarity. 


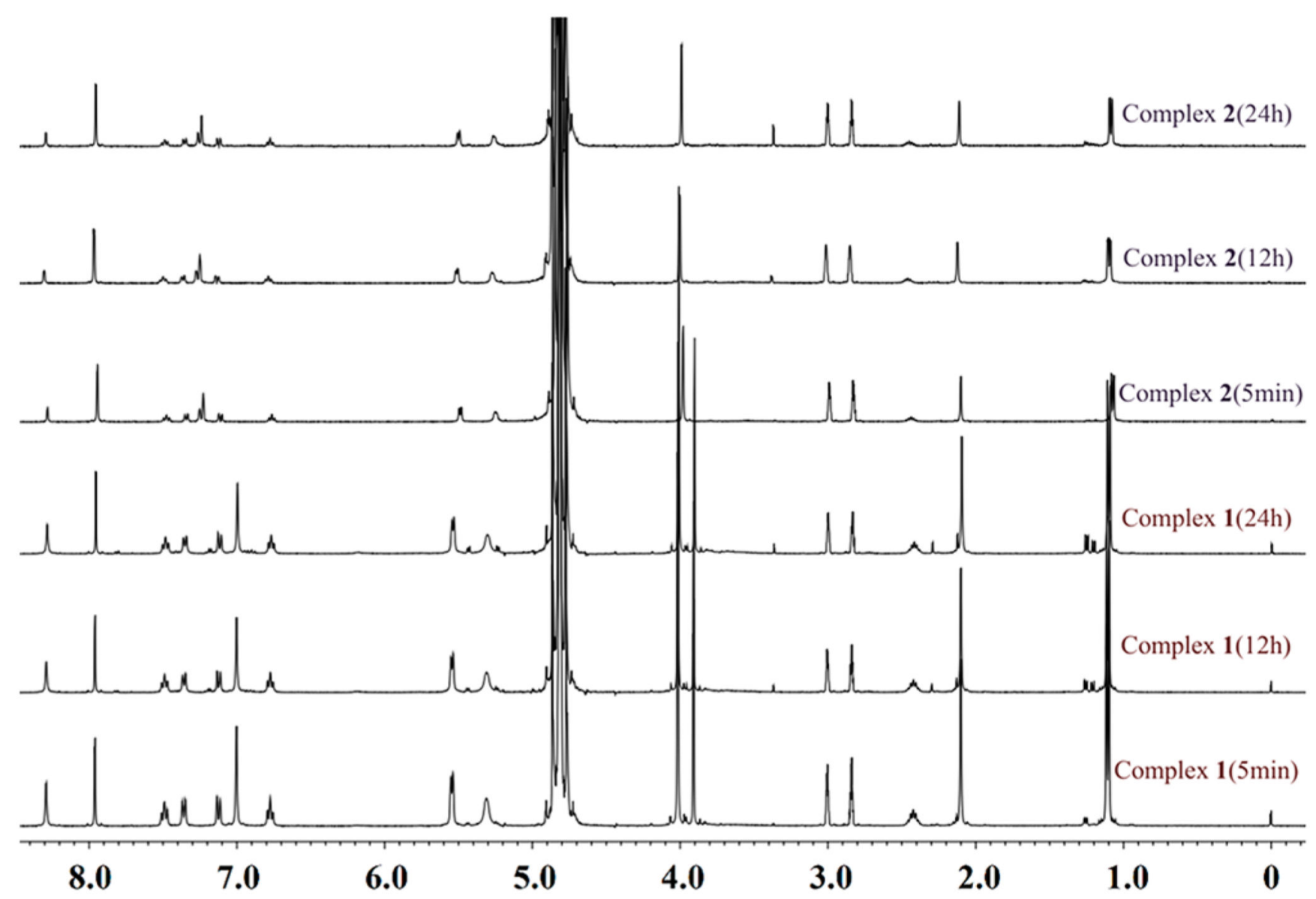

Figure 3.

Stability kinetics of complexes $\mathbf{1}$ and $\mathbf{2}$ in $20 \mathrm{mM}$ phosphate buffer (pH 7.4) with $4 \mathrm{mM}$ $\mathrm{NaCl}$ and $10 \%$ DMF- $d_{7}$. Data for each of the complexes are separately plotted in Figures S21-S23 for the sake of clarity. 


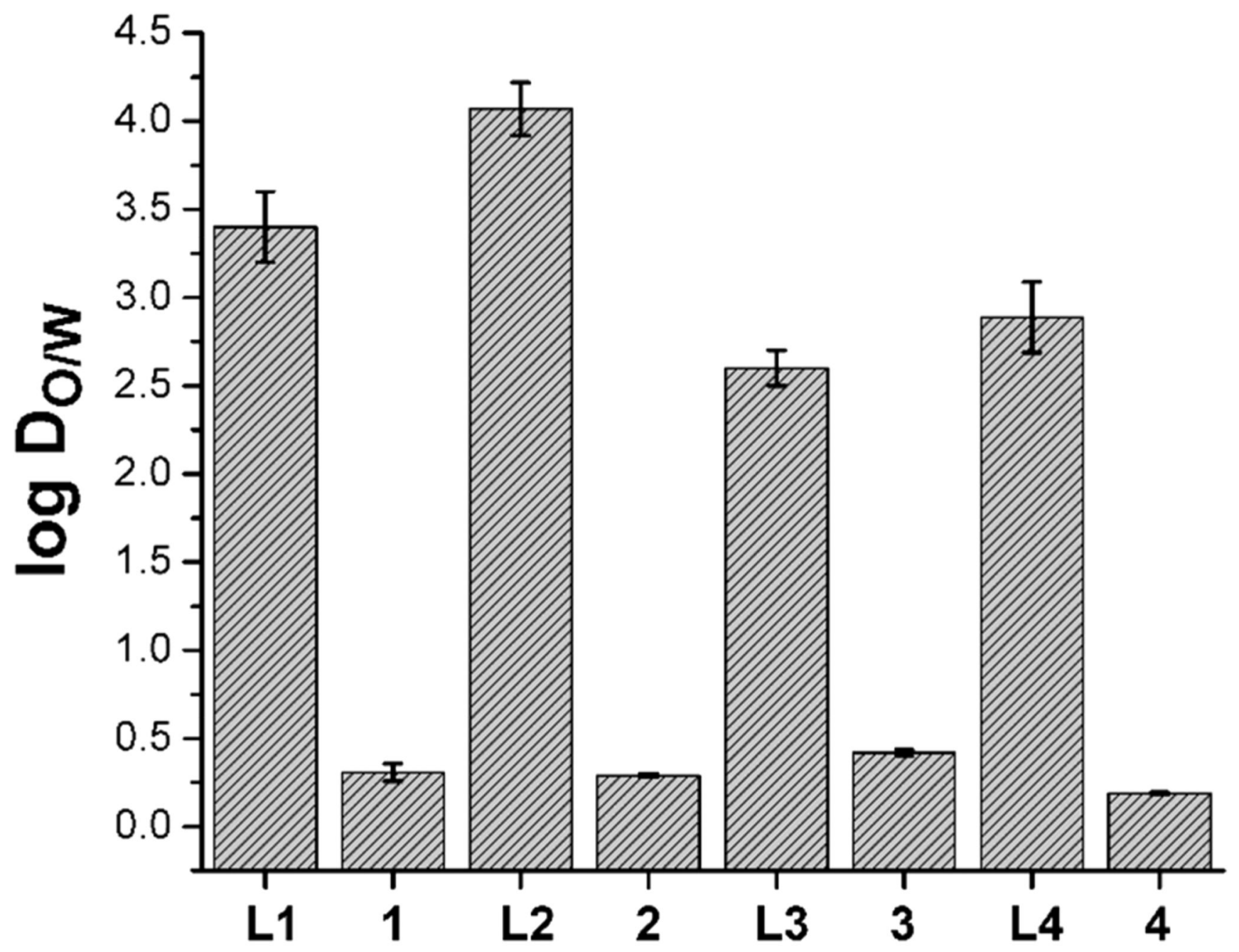

Figure 4.

Lipophilicity of the ligands (L1-L4) and their corresponding metal complexes (1-4) in a 1:1 (v/v) octanol/water mixture at $37^{\circ} \mathrm{C}$. 


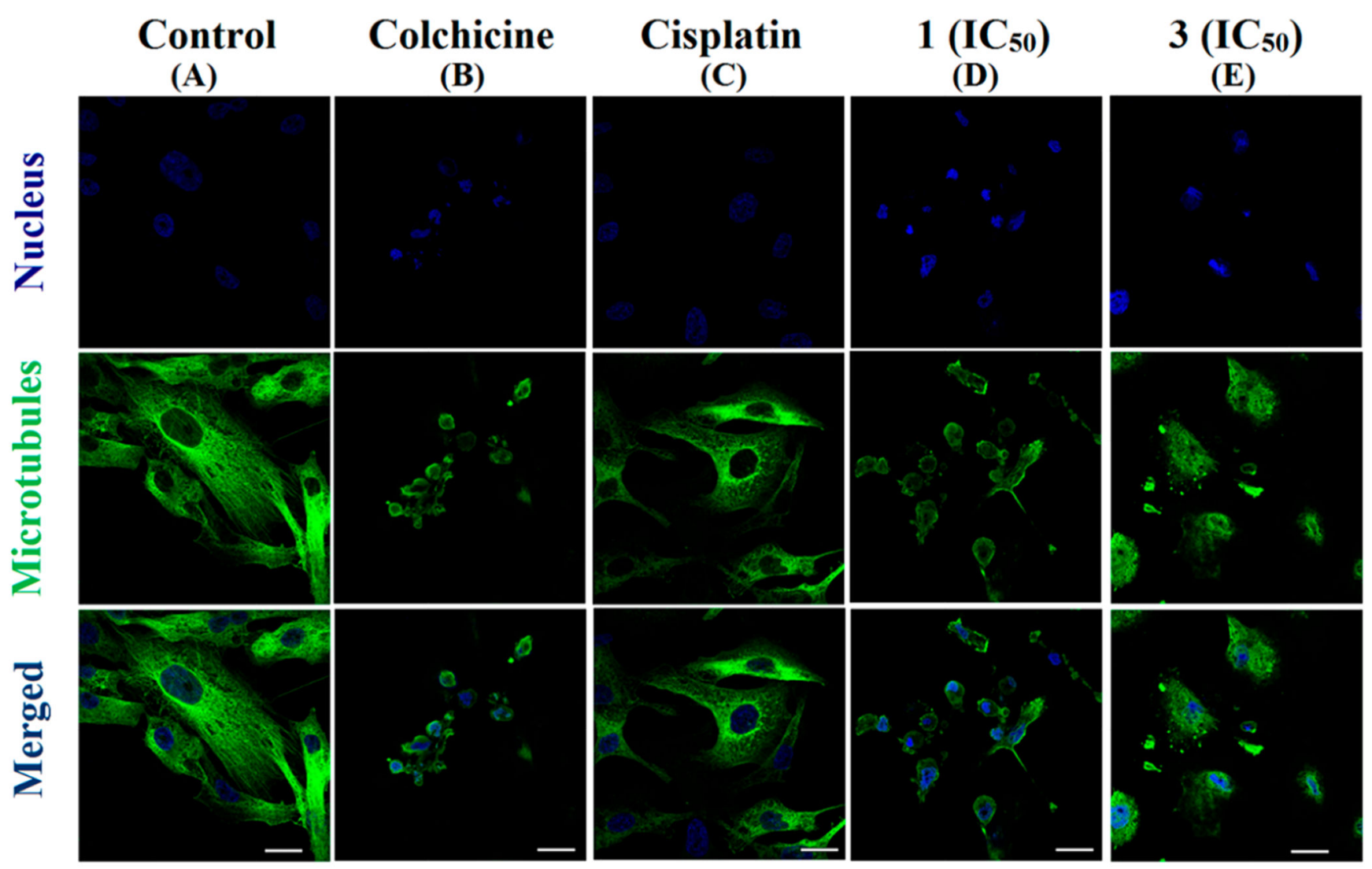

Figure 5.

Immunofluorescence study of the disruption of the microtubule network in MDA-MB-231 cells after incubation for $12 \mathrm{~h}$ in the presence of (A) $0.1 \%$ DMSO, (B) colchicine (100 nM), (C) cisplatin $(50 \mu \mathrm{M})$, (D) $\mathbf{1}\left(\mathrm{IC}_{50}\right)$, and (E) $3\left(\mathrm{IC}_{50}\right)$. Microtubules were visualized with a monoclonal anti- $\boldsymbol{a}$-tubulin antibody (green) interacting with a secondary antibody tagged with AlexFluor $488\left(\lambda_{\mathrm{em}}=520 \mathrm{~nm}\right)$. The nucleus was stained with DAPI (blue). Images were acquired with a Leica SP8 confocal microscope with a $63 \times$ objective. The scale bar represents $20 \mu \mathrm{m}$. 


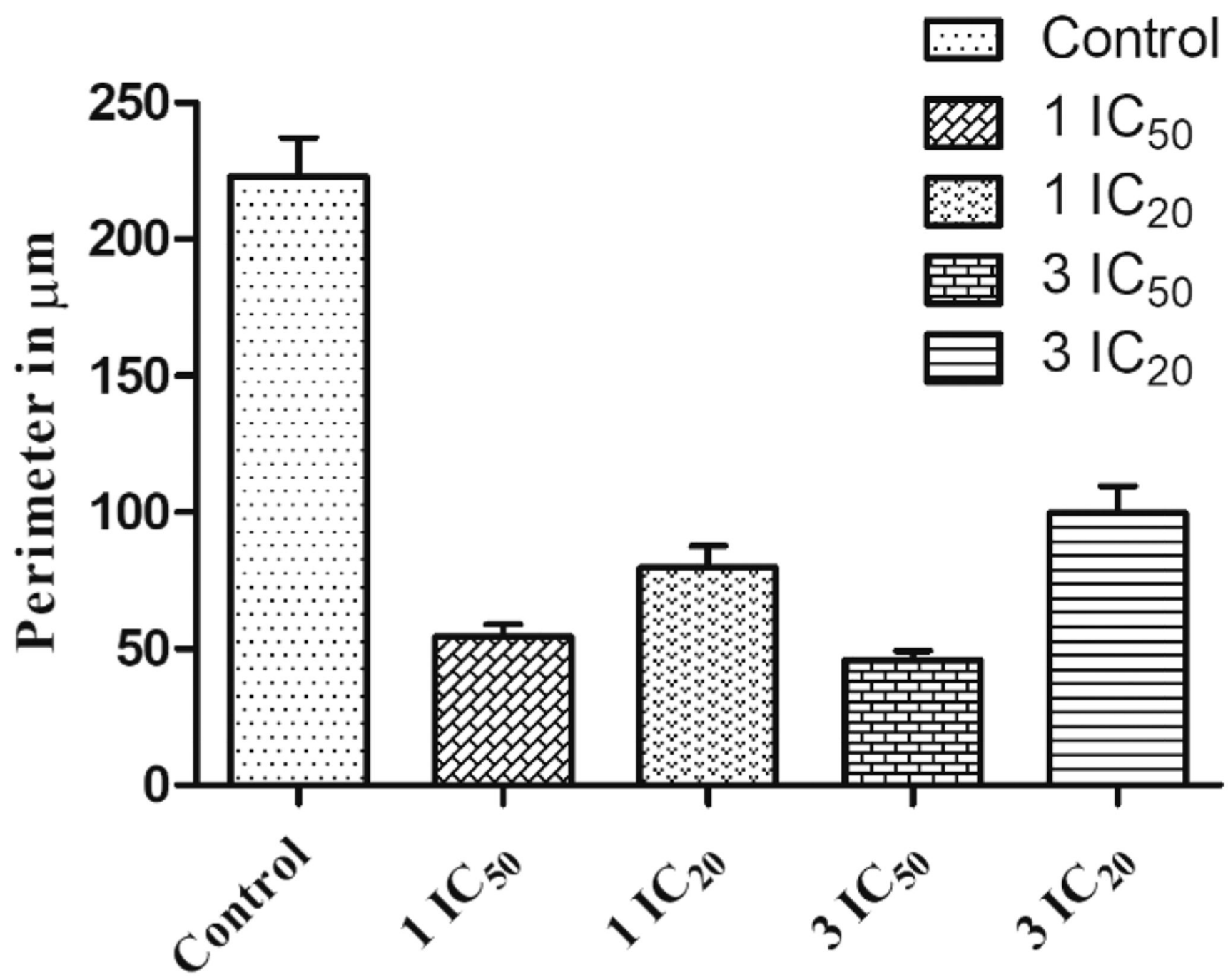

Figure 6.

Quantification of the inhibition of the microtubule network in MDA-MB-231 cells. 


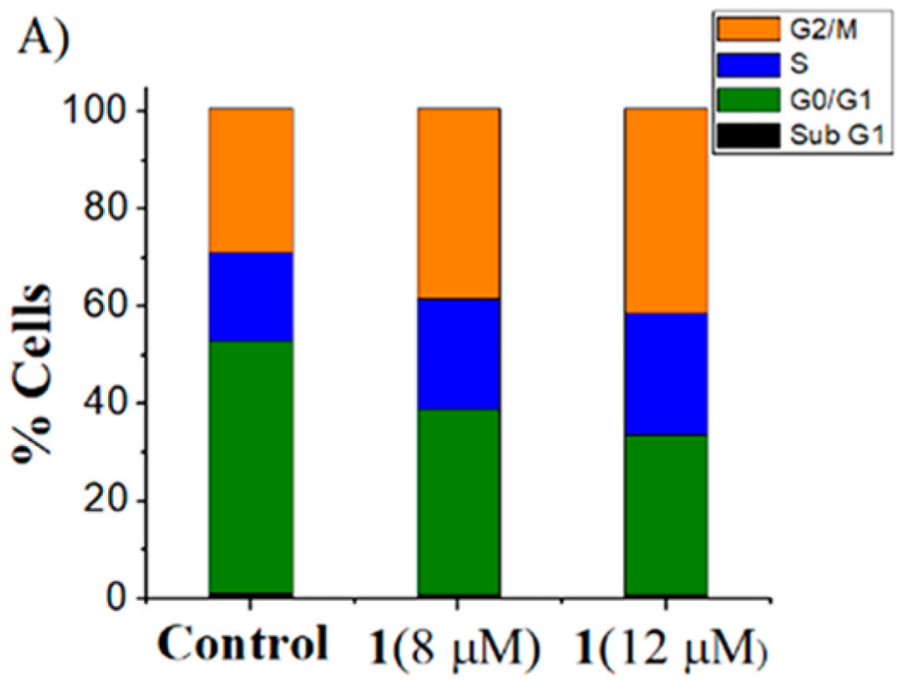

B)

C)

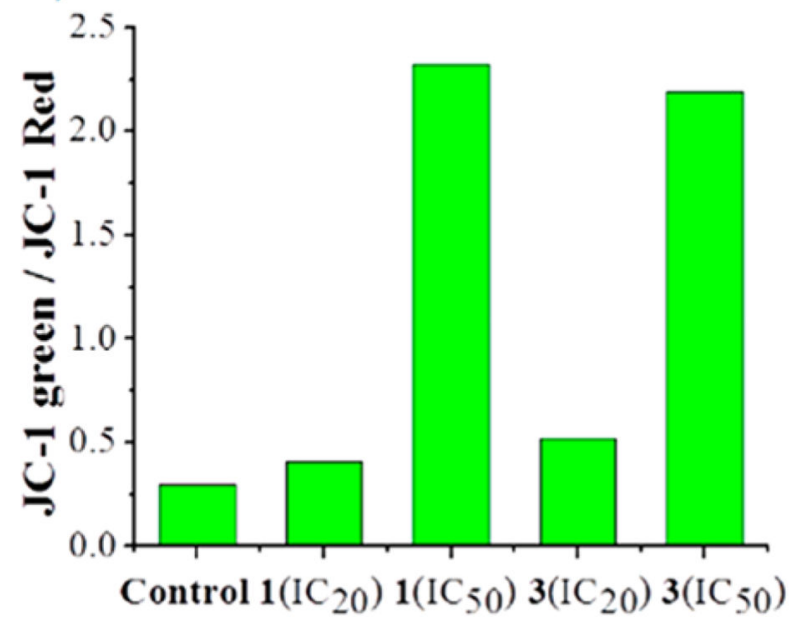

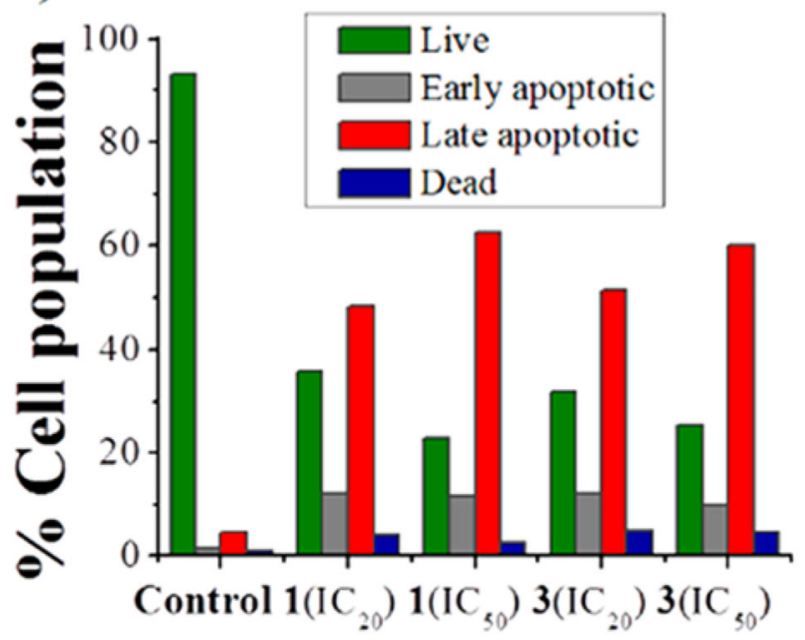

D)

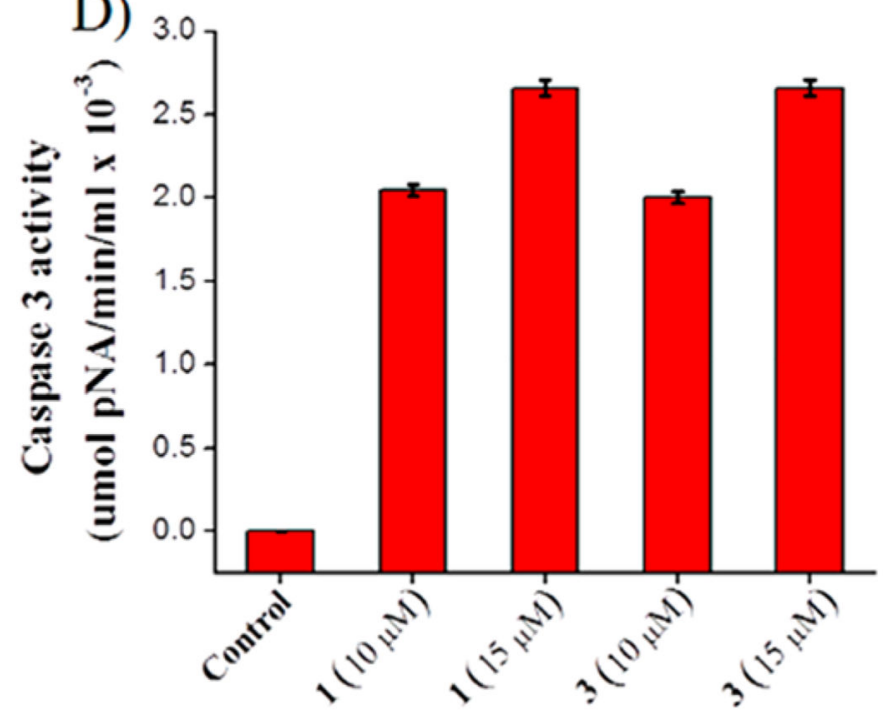

Figure 7.

In vitro mechanistic studies of the apoptotic pathway of the complexes. (A) Cell cycle arrest in the G2/M phase by 1 in a dose-dependent manner ( 8 and $12 \mu \mathrm{M})$ in the MDA-MB-231 cell line. (B) Induction of apoptosis by complexes $\mathbf{1}$ and $\mathbf{3}$ in the MDA-MB-231 cell line in a dose-dependent manner. $(C)$ Influence on the change in the mitochondrial membrane potential of MDA-MB-231 cells treated with complexes $\mathbf{1}$ and $\mathbf{3}$ at their respective $\mathrm{IC}_{20}$ and $\mathrm{IC}_{50}$ concentrations for $18 \mathrm{~h}$ and stained with $\mathrm{JC}-1\left(5 \mu \mathrm{g} \mathrm{mL} \mathrm{L}^{-1}\right)$ analyzed by flow cytometry. (D) Colorimetric determination showing caspase 3 activation in the MDA-MB-231 cell line with $\mathbf{1}$ and $\mathbf{3}$ at two different concentrations for $24 \mathrm{~h}$. 
<smiles>[R]c1cccc(C=O)c1O</smiles><smiles>[R]CC([R20])c1cc(N)cc([R])c1[R2]</smiles><smiles>[R]c1cc(N=Cc2cccc([R])c2O)cc([R])c1[R2]</smiles>

[R

L1: $\mathrm{R}_{1}=\mathrm{R}_{2}=\mathrm{R}_{3}=\mathrm{OMe} ; \mathrm{R}=\mathrm{H}$

L2: $\mathrm{R}_{1}=\mathrm{H} ; \mathrm{R}_{2}=\mathrm{R}_{3}=\mathrm{OMe} ; \mathrm{R}=\mathrm{H}$

L3: $\mathrm{R}_{1}=\mathrm{R}_{2}=\mathrm{R}_{3}=\mathrm{OMe} ; \mathrm{R}=\mathrm{OMe}$

L4: $\mathrm{R}_{1}=\mathrm{H} ; \mathrm{R}_{2}=\mathrm{R}_{3}=\mathrm{OMe} ; \mathrm{R}=\mathrm{OMe}$

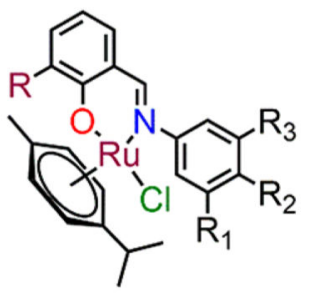

1: $\mathrm{R}_{1}=\mathrm{R}_{2}=\mathrm{R}_{3}=\mathrm{OMe} ; \mathrm{R}=\mathrm{H}$

2: $\mathrm{R}_{1}=\mathrm{H} ; \mathrm{R}_{2}=\mathrm{R}_{3}=\mathrm{OMe} ; \mathrm{R}=\mathrm{H}$

3: $\mathrm{R}_{1}=\mathrm{R}_{2}=\mathrm{R}_{3}=\mathrm{OMe} ; \mathrm{R}=\mathrm{OMe}$

4: $\mathrm{R}_{1}=\mathrm{H} ; \mathrm{R}_{2}=\mathrm{R}_{3}=\mathrm{OMe} ; \mathrm{R}=\mathrm{OMe}$

Scheme 1. Synthesis of Ligands (L1-L4) and Ruthenium Complexes (1-4) 
Table 1

Selected Bond Distances (angstroms) for Complexes 1, 3, and 4

\begin{tabular}{cll}
\hline \multicolumn{1}{c}{$\mathbf{1}$} & \multicolumn{1}{c}{$\mathbf{3}$} & \multicolumn{1}{c}{$\mathbf{4}$} \\
\hline $\mathrm{Ru} 1-\mathrm{C} 11,2.4268(6)$ & $\mathrm{Ru} 1-\mathrm{C} 11,2.4453(4)$ & $\mathrm{Ru} 1-\mathrm{C} 11,2.4345(5)$ \\
$\mathrm{Ru} 1-\mathrm{O} 1,2.0590(15)$ & $\mathrm{Ru} 1-\mathrm{O} 1,2.0752(11)$ & $\mathrm{Ru} 1-\mathrm{O} 1,2.0795(15)$ \\
$\mathrm{Ru} 1-\mathrm{N} 1,2.0812(18)$ & $\mathrm{Ru} 1-\mathrm{N} 1,2.0659(13)$ & $\mathrm{Ru} 1-\mathrm{N} 1,2.0807(18)$ \\
$\mathrm{Ru} 1-\mathrm{C} 17,2.192(2)$ & $\mathrm{Ru} 1-\mathrm{C} 18,2.1867(16)$ & $\mathrm{Ru} 1-\mathrm{C} 16,2.186(2)$ \\
$\mathrm{Ru} 1-\mathrm{C} 18,2.167(2)$ & $\mathrm{Ru} 1-\mathrm{C} 19,2.1774(16)$ & $\mathrm{Ru} 1-\mathrm{C} 17,2.165(2)$ \\
$\mathrm{Ru} 1-\mathrm{C} 19,2.186(2)$ & $\mathrm{Ru} 1-\mathrm{C} 20,2.1836(16)$ & $\mathrm{Ru} 1-\mathrm{C} 18,2.159(2)$ \\
$\mathrm{Ru} 1-\mathrm{C} 20,2.195(2)$ & $\mathrm{Ru} 1-\mathrm{C} 21,2.1898(16)$ & $\mathrm{Ru} 1-\mathrm{C} 19,2.202(2)$ \\
$\mathrm{Ru} 1-\mathrm{C} 21,2.196(2)$ & $\mathrm{Ru} 1-\mathrm{C} 22,2.2066(17)$ & $\mathrm{Ru} 1-\mathrm{C} 20,2.200(2)$ \\
$\mathrm{Ru} 1-\mathrm{C} 22,2.176(2)$ & $\mathrm{Ru} 1-\mathrm{C} 23,2.1928(16)$ & $\mathrm{Ru} 1-\mathrm{C} 21,2.204(2)$ \\
\hline
\end{tabular}


Table 2

Selected Bond Angles (degrees) for Complexes 1, 3, and 4

\begin{tabular}{ccc}
\hline \multicolumn{1}{c}{$\mathbf{3}$} & $\mathbf{4}$ \\
\hline O1-Ru1-C11, 86.02(5) & O1-Ru1-C11, 85.23(3) & O1-Ru1-C11, 87.80(4) \\
O1-Ru1-N1, 87.84(6) & N1-Ru1-O1, 88.37(5) & O1-Ru1-N1, 87.91(6) \\
N1-Ru1-C11, 84.08(5) & N1-Ru1-C11, 84.10(4) & N1-Ru1-C11, 83.84(5) \\
O1-Ru1-C17, 94.90(7) & O1-Ru1-C18, 91.04(5) & N1-Ru1-C16, 124.46(8) \\
O1-Ru1-C18, 127.81(8) & O1-Ru1-C19, 121.32(6) & N1-Ru1-C17, 96.45(8) \\
O1-Ru1-C19, 163.53(8) & O1-Ru1-C20, 158.90(6) & N1-Ru1-C18, 92.60(7) \\
O1-Ru1-C20, 142.05(8) & O1-Ru1-C21, 149.36(5) & N1-Ru1-C19, 115.08(8) \\
O1-Ru1-C21, 105.99(8) & O1-Ru1-C22, 111.93(5) & N1-Ru1-C20, 152.10(8) \\
O1-Ru1-C22, 86.18(7) & O1-Ru1-C23, 88.20(5) & N1-Ru1-C21, 162.31(8)
\end{tabular}


Table 3

In Vitro Anticancer Activity of Complexes 1-4 in Various Cancer Cell Lines under Normoxic and Hypoxic Conditions

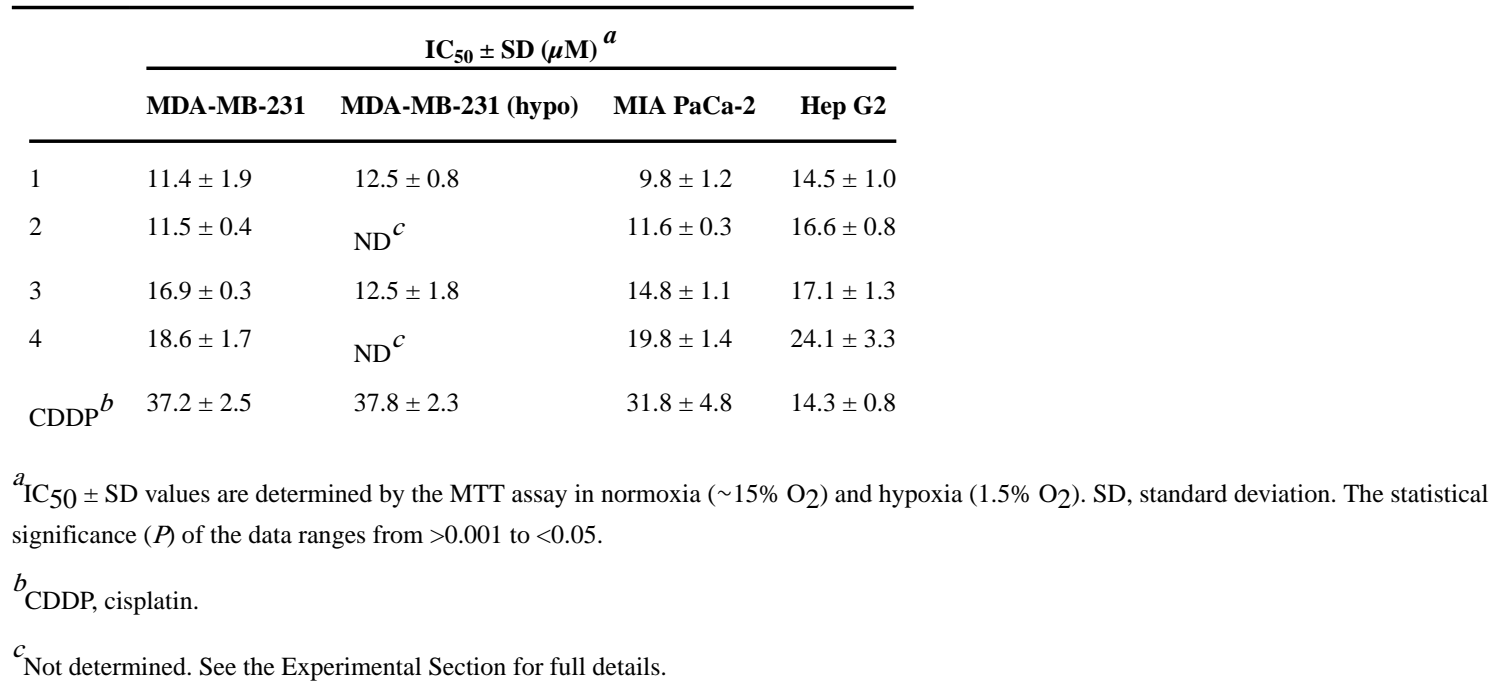

